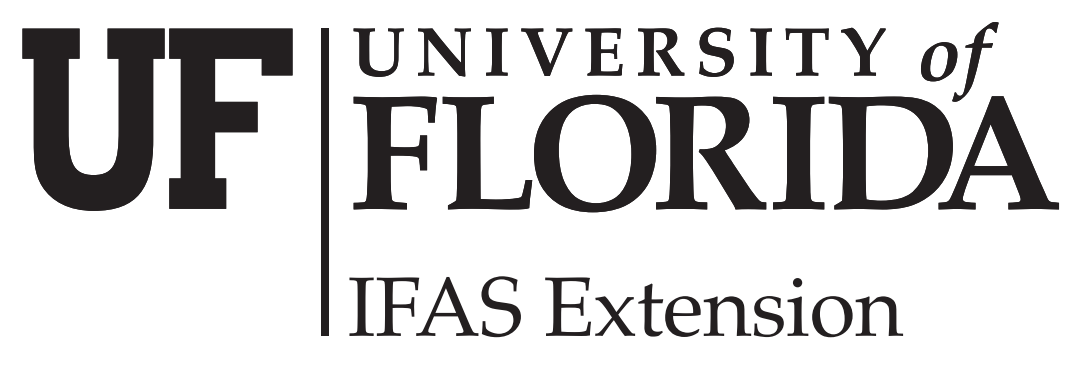

CIR1521

\title{
Spatially Continuous Interpolation of Water Stage and Water Depths Using the Everglades Depth Estimation Network (EDEN) ${ }^{1}$
}

Leonard Pearlstine, Aaron Higer, Monica Palaseanu, Ikuko Fujisaki, and Frank Mazzotti²

1. This document is CIR1521, one of a series of the Wildlife Ecology and Conservation Department, Florida Cooperative Extension Service, Institute of Food and Agricultural Sciences, University of Florida. Original publication date July 2007. Minor Revision: September 2007. Visit the EDIS Web Site at http://edis.ifas.ufl.edu.

2. Leonard Pearlstine, assistant scientist, UF/FLREC; Aaron Higer, Assistant Scientist, University of Florida; Monica Palaseanu, former UF spatial analyst and post-doctoral associate; Ikuko Fujisaki, statistical analyst and post-doctoral associate, Frank J. Mazzotti, associate professor, FLREC and Department of Wildlife Ecology and Conservation

The Institute of Food and Agricultural Sciences (IFAS) is an Equal Opportunity Institution authorized to provide research, educational information and other services only to individuals and institutions that function with non-discrimination with respect to race, creed, color, religion, age, disability, sex, sexual orientation, marital status, national origin, political opinions or affiliations. U.S. Department of Agriculture, Cooperative Extension Service,

University of Florida, IFAS, Florida A. \& M. University Cooperative Extension Program, and Boards of County Commissioners Cooperating. Larry Arrington, Dean 


\section{Table of Contents}

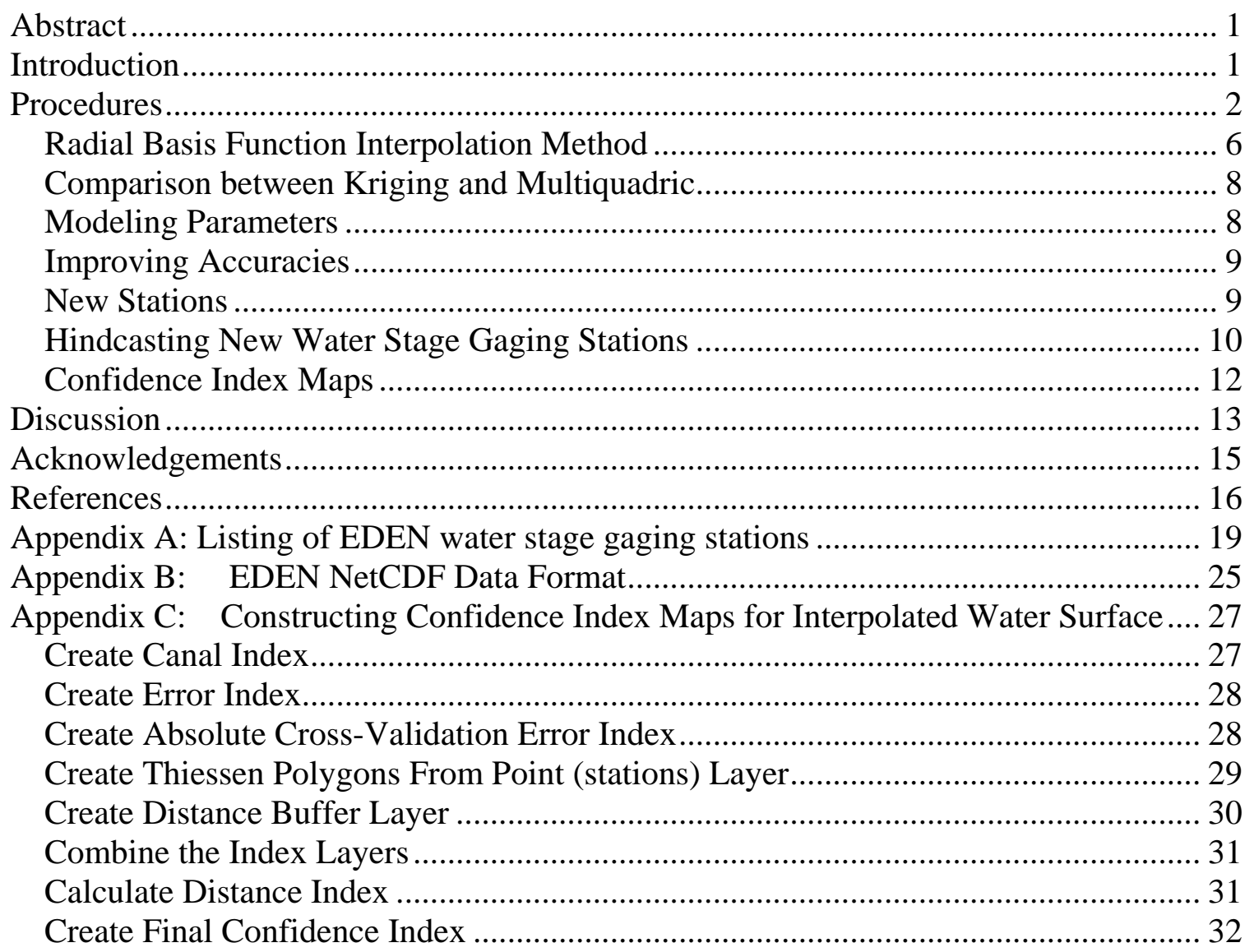




\section{Abstract}

The Everglades Depth Estimation Network (EDEN) is an integrated network of real-time water-level monitoring, ground-elevation modeling, and water-surface modeling that provides scientists and managers with current (2000-present), on-line water-stage and water-depth information for the entire freshwater portion of the Greater Everglades. Continuous daily spatial interpolations of the EDEN network stage data are presented on a 400-square-meter grid spacing. EDEN offers a consistent and documented dataset that can be used by scientists and managers to (1) guide large-scale field operations, (2) integrate hydrologic and ecological responses, and (3) support biological and ecological assessments that measure ecosystem responses to the implementation of the Comprehensive Everglades Restoration Plan (CERP). The target users are biologists and ecologists examining trophic level responses to hydrodynamic changes in the Everglades.

\section{Introduction}

Spatially explicit hydrologic information can be critical in understanding and predicting changes in biotic communities in wetland ecosystems. In Florida's Everglades there have been numerous efforts to measure and link daily and seasonally fluctuating surface water depth to biotic communities. Repeated field measurement is a traditional way to obtain such information, but it is labor intensive and does not provide information on continuous spatial variability across a large area. Taking systematic field measurements across space and time is difficult since the Everglades comprise remote and inaccessible areas. Alternatively, hydrologic models are frequently used in ecological research in the Everglades (Walters et al. 1992; Curnutt et al. 2000; Immanuel et al. 2005).

Over 200 real-time stage monitoring gages have been placed throughout the Everglades by various agencies with different monitoring needs to automatically measure stage and radio-transmit the data. The Everglades Depth Estimation Network (EDEN) is funded by the Comprehensive Everglades Restoration Plan (CERP) and US Geological Survey (USGS) Priority Ecosystem Sciences (PES) with collaborative support between federal and state government agencies, scientists in south Florida, and University of Florida. This project integrates existing and new telemetered water-level gages into a single network and, in combination with high resolutions ground elevation modeling, generates a daily continuous water surface and water depth for the freshwater greater Everglades. This provides investigators with tools to infer other hydrologic characteristics such as recession rates, time since last dry period and water-surface slope.

This report documents the procedures used in generation of EDEN water stage and water depth interpolated surfaces. 


\section{Procedures}

The water surface model follows the steps illustrated in Figure 1 and are detailed in this section:

1. Water-level data for all the EDEN gages are retrieved from an ftp server.

2. Water-level data reported in NGVD 29 are converted to NAVD 88

3. Daily median water level is calculated.

4. Linear interpolation is used to create boundary conditions along canals and levees.

5. Radial Basis Function multiquadric interpolation of extended data (median water level from gages in marsh and interpolated values along canals) is used to generate continuous water level surfaces daily.

6. The continuous water surface is predicted on the EDEN grid (400 m x $400 \mathrm{~m}$ ).

7. Water depth is estimated by subtracting the EDEN ground digital elevation model (DEM) from the predicted water surface.

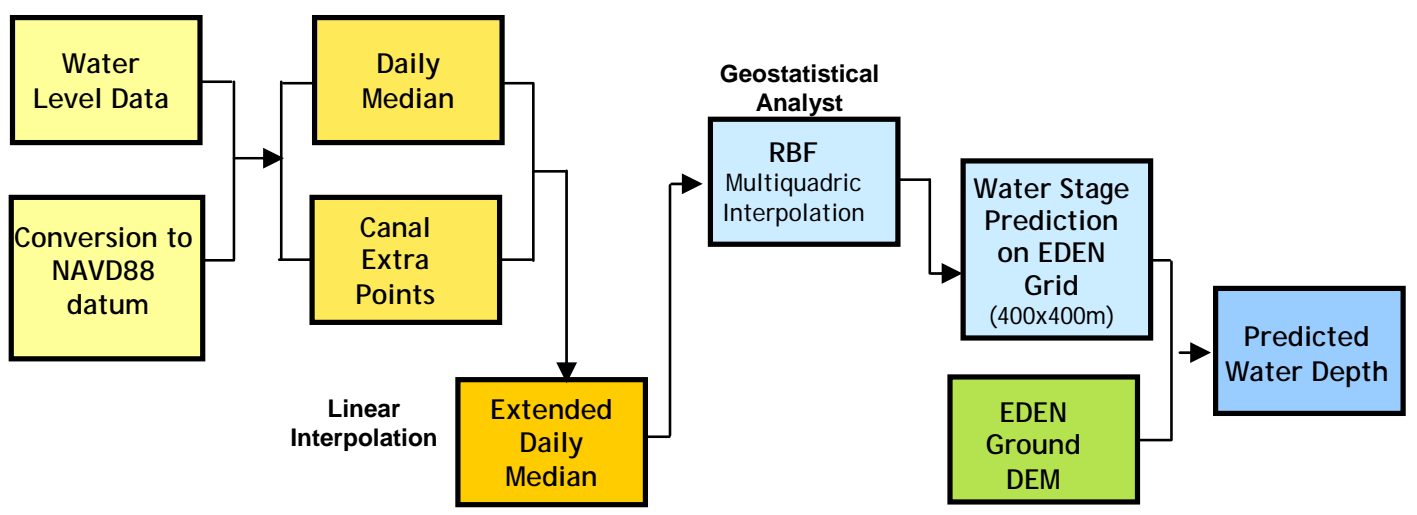

Figure 1. Flow chart of water stage and water depth modeling for EDEN.

The USGS retrieves water level data daily from 253 gaging stations including 225 telemetry-enhanced gages that record and transmit several water level values throughout the day, mostly hourly from recorders ranging approximately from $81^{\circ} 07^{\prime} 19 \mathrm{~W}$ to 80 ${ }^{\circ} 13^{\prime} 05 \mathrm{~W}$ in easting and $25^{\circ} 13^{\prime} 27 \mathrm{~N}$ to $26^{\circ} 40^{\prime} 47 \mathrm{~N}$ in northing in south Florida. An additional 28 gages do not have telemetry and are manually read and added to the network (Figure 2 and Appendix A). All transmitted data are entered and stored in the National Water Information System (NWIS), a database operated by the United States Geological Survey (USGS). The 13 USGS gages in the EDEN network bordering the Gulf of Mexico are not used in the surfacing interpolations described in this report. There are a total of 240 gages used for water surface interpolation of the freshwater Everglades. 
All gages in the EDEN network are operated and maintained by four separate agencies including Everglades National Park (ENP), South Florida Water Management District (SFWMD), Big Cypress National Preserve (BCNP), and the USGS. The NWIS database transmits all recorded data to a local USGS FTP server where it is available for surfacing. Gage data and its metadata are available for preview and downloading at the EDENweb (http://sofia.usgs.gov/eden).

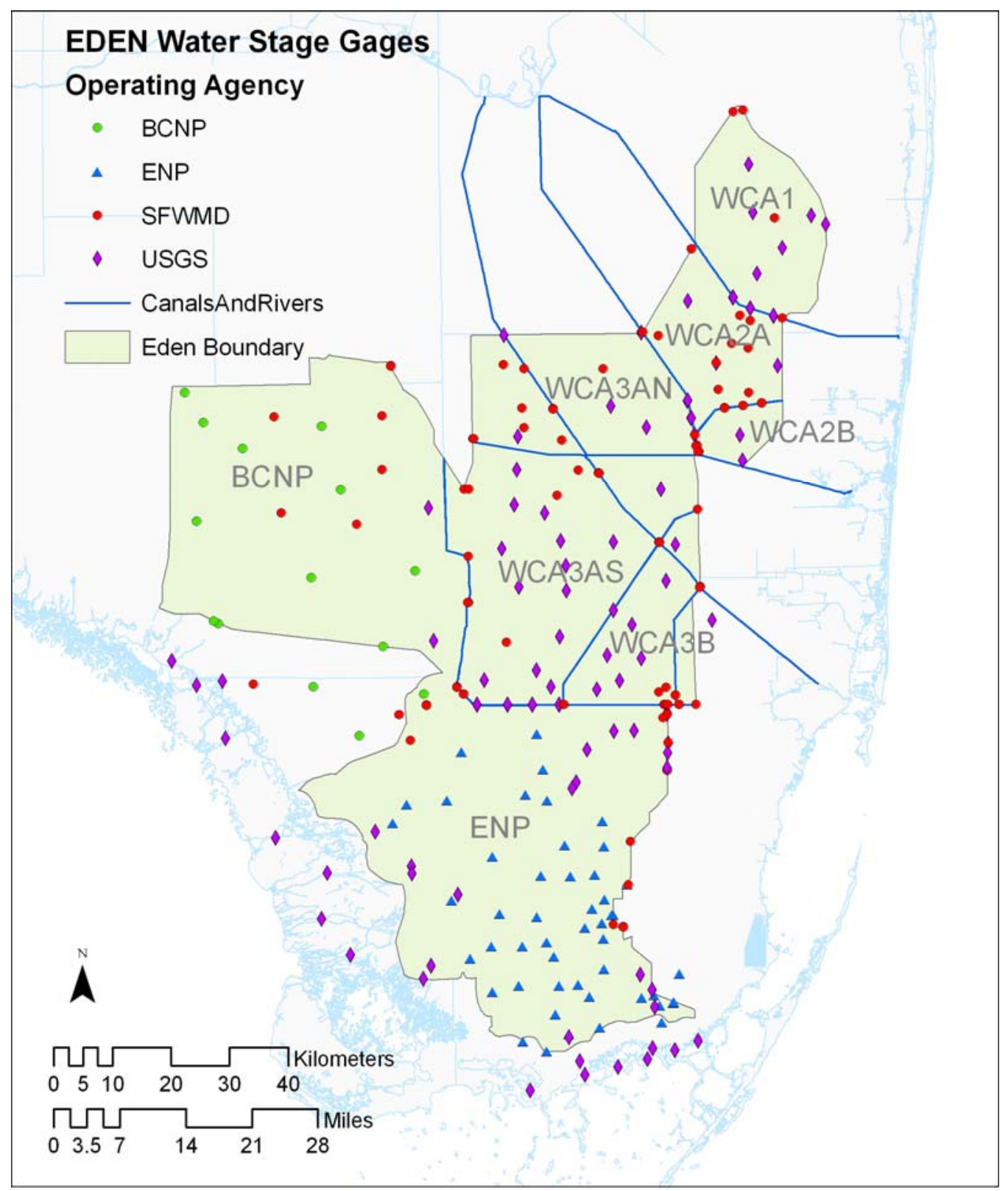

Figure 2. Location of water stage gages collected in the EDEN network. Water Conservation Areas (WCA) 2 and 3 are subdivided by canals. WCA3A is further subdivided into a northern (WCA3AN) and southern (WCA3AS) region. 
The EDEN area is divided in 8 distinct sections by canals and levees, with 5 sections belonging to three distinct water conservation areas surrounded by canals and levees (Figure 2). Abrupt water level discontinuities among the sections complicate interpolation across the entire area. Water level near section boundaries is further influenced by the SFWMD's operation of massive pumps and canals to distribute water for natural areas, agriculture, urban use and flood protection.

The gaging stations fall generally into 2 categories: marsh stations (away from canals) and canal stations. In locations where canal stations are at a structure across a levee, gages are frequently paired so that there is a gage on both sides of the levee to measure differences in water stage created by the levee and structure. These paired gaging stations are referred to as "head" and "tail" stations (Figure 3). Canal stations may or may not have a continuous hydrologic connection with stations further out in the marsh.

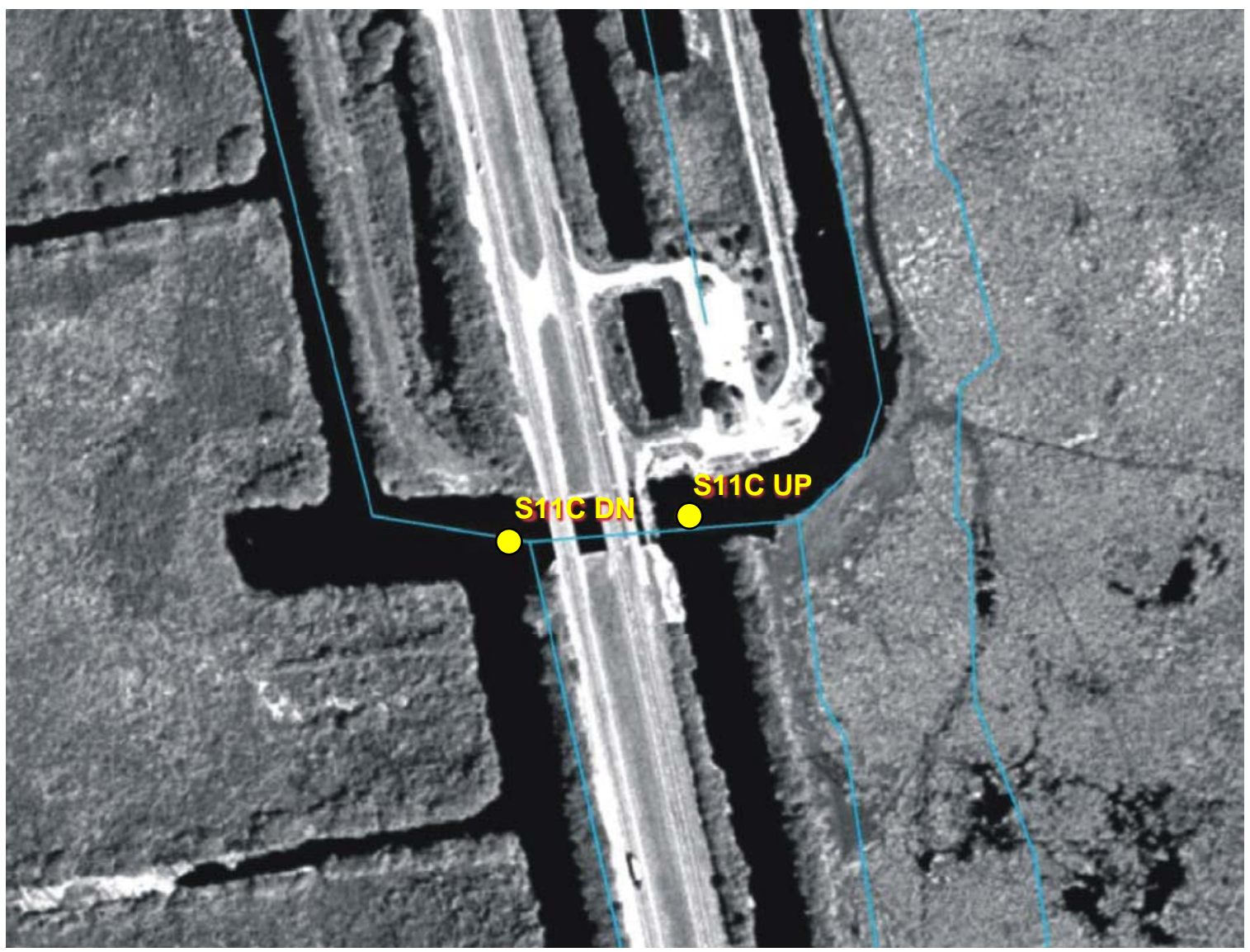

Figure 3. Example of head and tail gaging stations at S-11C. S-11C is a control structure in the levee dividing Water Conservation Area 2A from Water Conservation Area 3ANorth.

To prepare a range of dates for surfacing, data retrieved from gaging stations in National Geodetic Vertical Datum of 1929 (NGVD 29) is converted to North American 
Vertical Datum of 1988 (NAVD 88) (Telis, 2006) and the median value for each day is calculated. Daily median values are used for the interpolation algorithm to reduce the influence of occasional incorrect extreme values in the data.

The canal and levee boundaries act as major discontinuities in the EDEN area, and water levels from one section have minimal or no influence into adjacent sections. Steep changes in elevation can occur between areas at these levees. Since stratification of the data is not feasible due to the limited number of water gages, boundary conditions were simulated by linearly interpolating along both sides of levels in the canals using head and tail stage data. Simulated data at these pseudo-stations were re-sampled every $200 \mathrm{~m}$ and re-introduced into the interpolation exercise (Figure 4). The marsh gage data together with the interpolated data along canals represent the new extended data used for water surface modeling. In this way, data from the marsh in one conservation area would not influence the values in the marsh across a canal in a different area. Even though track data (very densely sampled preferential lines) alone may be problematic for interpolation, our mixture of track data along canals and levees, plus randomly distributed stage data, and the provision to use only the closest data point to the interpolated location in each of the 8 sectors of a search neighborhood (see below) overcomes some of the problems. Nevertheless, we still place a reduced confidence in the interpolated surface close to canal data.

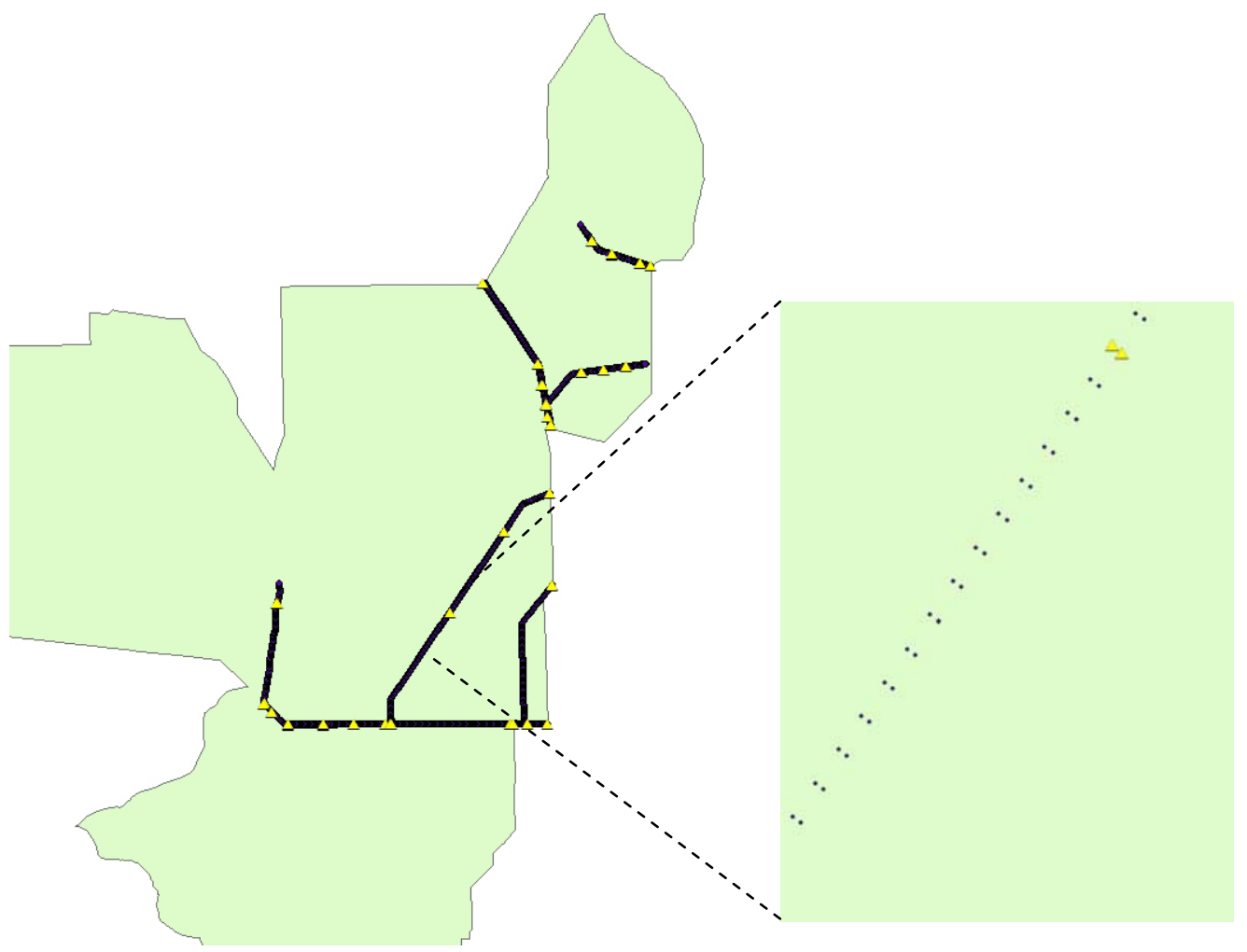

Figure 4. Levee and canal locations where boundary conditions were created for interpolation. The yellow triangles are the locations of water stage gages. The close-up illustrates linear interpolation of head and tail pseudo-stations every $200 \mathrm{~m}$ along a levee. 
Using Geostatistical Analyst in ArcGIS 9.x (Johnston et al. 2001, radial basis function interpolation with the multiquadric method was used to create a continuous mathematical representation of the water surface that was sampled further on a $400 \times 400$ $\mathrm{m}$ grid spacing to record the interpolated values. These results are combined with a digital elevation model (DEM) to obtain daily water depths (Figure 5). Details of EDEN grid, ground surface elevation sampling and modeling are in Jones and Price (2007a) and Jones and Price (2007b). The 400m x 400 m interpolated grid is stored in NetCDF format (Appendix B) which allows rapid retrieval of geo-coded time-series data and import into ArcGIS.

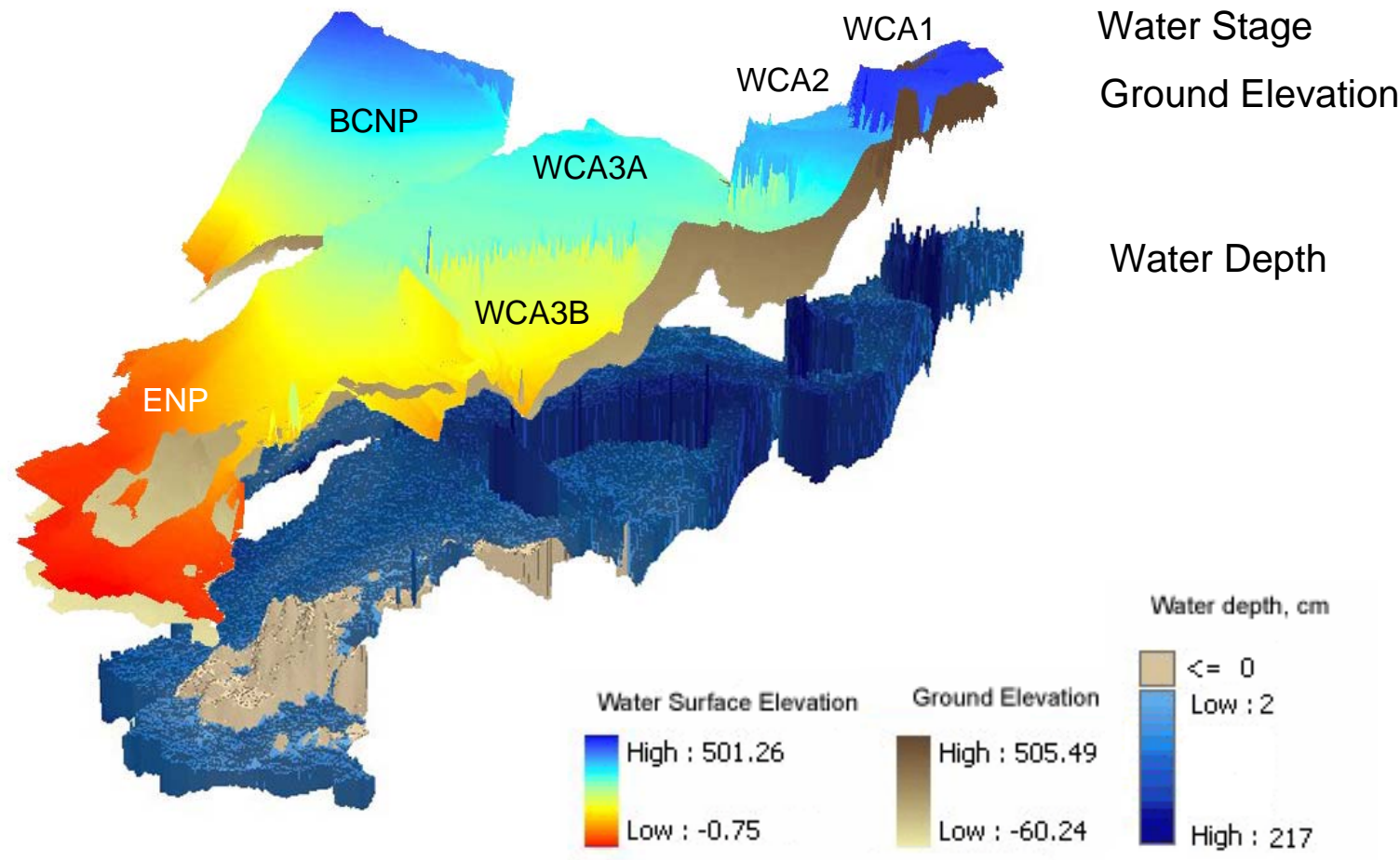

Figure 5. Water stage minus ground elevation produces an estimate of water depth. The tan area in Everglades National Park (ENP) is where ground surface is above the water surface. This example is for a sample day in November 2005. Vertical units are cm, NAVD 88.

\section{Radial Basis Function Interpolation Method}

The multiquadric method was first established by Hardy in1968 and made public in 1971 (Hardy, 1971 1977). Later it was demonstrated mathematically that this method is a case of biharmonic analysis in an arbitrary number of dimensions (Dyn and Levin, 
1980, 1983, Barnhill and Stead, 1984, Hardy and Nelson, 1986, Michelli, 1986, Foley, 1987, Madych and Nelson, 1990). The multiquadric equations are also continuously differentiable integrals. The method was tested on both "real world" data in geophysics, surveying and mapping, photogrammetry and remote sensing, digital terrain models and hydrology, as well as on mathematical surfaces. Franke (1982) gave a critical account and comparison of 29 interpolation methods tested on generated mathematical surfaces from sparse and scattered data. None of the methods investigated by Franke (1982) belonged to the kriging family. Hardy's multiquadric method performed the best or the second best in Franke's study: "In terms of fitting ability and visual smoothness, the most impressive method included in the tests is the "multiquadric" method, due to Hardy. ... The method ... yields consistently good results, often giving the most accurate results of all tested methods.” (Franke, 1982, pp. 191).

Radial Basis Function (RBF) is Referred to as an exact interpolation technique because the interpolated surface always passes exactly through the data points. RBF interpolations use a set of $\mathrm{n}$ radial basis functions, one for each location, while minimizing the total curvature of the surface (Johnston et al. 2001). Thus, the predictor is a linear combination of the radial basis function

$Z\left(s_{0}\right)=\sum_{i=1}^{n} \omega_{i} \phi(d)$

where $\phi(d)$ is a radial basis function with $d=\left\|s_{i}-s_{0}\right\|$ the Euclidian distance between the prediction location $\mathrm{s} 0$ and each known data location si and ${ }^{\omega_{i}}$ the equation weights. In Figure 6 for three different locations, the RBF surface is illustrated in a different line type. For a set of coordinates of a predicted value location, the predictor will be formed by summing the weighted functions $\phi_{1}, \phi_{2}, \phi_{3}$ for each known location. Weighting enforces the condition that when predicting a measured value, this value is predicted exactly (Johnston et al. 2001). One difference between a simple Inverse Distance Weighting (IDW) and RBF interpolation is that IDW will have no predicted values below or above the minimum or maximum measured values, respectively. RBF predicted values, however, could be outside the measured values interval.

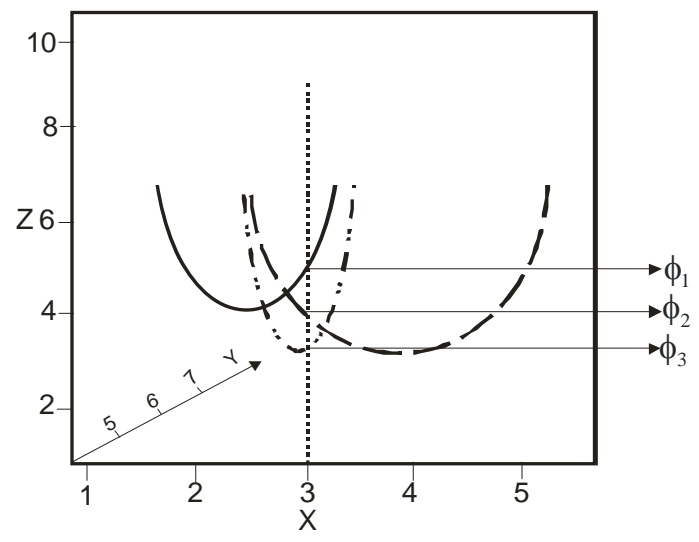

Figure 6. RBF prediction concept (modified after Johnston et al. 2001, p. 127) $Z(x, y)=w_{1} \phi_{1}+w_{2} \phi_{2}+w_{3} \phi_{3}$, where $x=3, y=4$ 
The radial basis function selected for this study uses the multiquadric function, defined as: $\phi(d)=\left(d^{2}+r^{2}\right)^{1 / 2}$, where $r$ is the smoothing or the shape parameter. If $r$ is small, the resulting interpolated surface has minimal curvature forming a cone like basis function with the generated surface being very "tight" around the data points (Kansa and Carlson 1992; Golberg et al. 1996; Johnston et al. 2001). As $r$ increases, the curvature of the function gradually flattens until the basis function is almost flat (Kansa and Carlson 1992; Golberg et al. 1996). There is much discussion about how to choose the shape parameter r, but no fool-proof method exists, only empirical formulas. The majority of the empirical formulas tie the parameter $r$ to the scale of the problem at hand, the distribution of data, and their density (Hardy 1977; Gopfert 1977; Franke 1982; Golberg et al.1996; Rippa 1999; and Ferreira et al. 2005). Others made the parameter $r$ dependent only to the data points measured value zi (Carlson and Foley, 1991) or used a variable parameter $r$ instead of a constant one for large datasets (Kansa, $1990 \mathrm{a}$ and b, Kansa and Carlson, 1992).

\section{Comparison between Kriging and Multiquadric}

Sirayanone (1988, cited in Hardy, 1990) proved that the multiquadric method of interpolation generates a statistically unbiased result without being a stochastic method by setting the condition that the sum of the weight coefficients equals one. Hardy (1988) and Hardy and Sirayanone (1989) have proved that multiquadric and kriging methods have almost equal accuracy in bivariate distributions, multiquadric having the advantage to be easily transformed for stereo-viewing of 3D bodies, and does not require data stationarity as kriging does. Similar results regarding the equivalency of kriging and multiquadric interpolation results have been reported by Myers (1994) and Borga and Vizzaccaro (1997). Syed et al. (2003) using rainfall data has demonstrated that multiquadric and kriging produce comparable results when variograms are developed using data from specific events, although kriging had inferior results when the variogram parameters were developed from monthly averages.

\section{Modeling Parameters}

In ArcGIS 9.x, the following parameters are selected:

- Input files are

1. An extended data file for median water levels at each gage and each resampled point between canal gages

2. An empty EDEN grid used as a template for final output grid has the following characteristics:

- UTM, zone $17 \mathrm{~N}, \mathrm{NAD} 1983$, units: meters

- Cell size: 400 x 400 meters

- Bounding rectangle: Top: 2952000.0m Bottom: 2790000.0m

Left: 463200.0m Right: 578000.0m 
3. DEM at $400 \times 400 \mathrm{~m}$ resolution matching the EDEN grid

4. EDEN boundary polygon for clipping the modeled output to the study area. The current EDEN boundary is smaller than the EDEN grid, allowing for future expansion.

- Water stage modeled for each day with the Radial Basis Function in Geostatistical Analyst is selected with the following parameters:

1. Kernel Functions: Multiquadric with a parameter $=16.77$

2. Neighbors to Include $=1$

3. Include at least $=1$

4. Shape type $=8$ sectors

5. Angle $=350$

6. Major semiaxis $=31000$

7. Minor semiaxis $=30000$

\section{Improving Accuracies}

Cross-validation errors are saved for each daily water surface produced. Factors that could influence cross-validation absolute errors of predicted water levels include minimum distance between stations and absolute difference between the measured values of each station to their respective nearest station measured value. Additional gages were added to the EDEN network, as described below, to improve water stage interpolations. A report on cross-validation errors as a function of nearest station measured values has been submitted for publication. As new publications and information are released, they will be cited at http://sofia.usgs.gov/eden .

\section{New Stations}

In 2006, new 23 stations (EDEN stations) were established based on proximity analysis of $400 \mathrm{~m}$ resolution grid maps in which each cell represents distance from the center of the cell to its nearest real-time station. Figure $7 \mathrm{a}$ is based on the distance from each grid to original real-time stations. Figure $7 \mathrm{~b}$ is based on the distance from each grid to all real-time stations including the ones converted to real-time (non-telemetered gages previously operated by Wiley Kitchens, USGS; and John Volin, Florida Atlantic University) and newly constructed EDEN stations. The gray scale indicates near (dark tone) to far (light tone) to the nearest station of each grid. Distances beyond 5,500 m were considered to be gaps in coverage based on neural network regressions by Paul Conrads, USGS (Unpublished) in WCA3 that generally demonstrated excellent predictions of water level at stations up to $6,000 \mathrm{~m}$ from an index station. Figure $7 \mathrm{~b}$ illustrates that conversion of Kitchens and Volin stations to real-time and addition of EDEN stations filled out the major gaps appearing in Figure 7a and thus, is expected to improve overall accuracy of spatial prediction of water depth. 


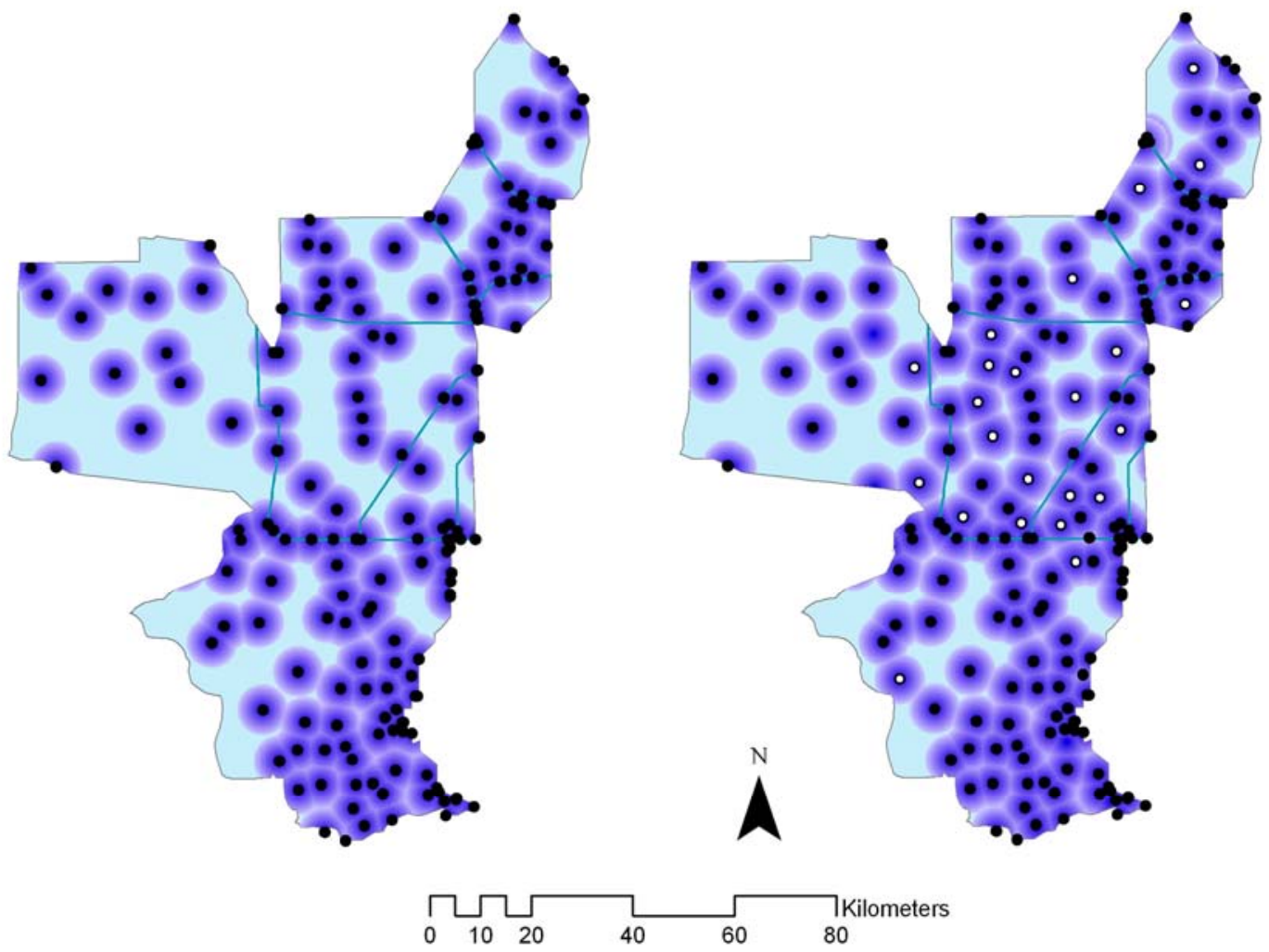

(a)

(b)

Figure 7. 400 m resolution maps based on distance from each grid to its nearest station before (a) and after (b) adding Kitchen, Volin, and new EDEN stations. The color gradient indicates near (dark tone) to far (light tone). New stations in (b) are indicated with white centers.

\section{Hindcasting New Water Stage Gaging Stations}

Daily gage data were compiled for all the stations in the EDEN network for the period beginning January 2000 to current, except for the new stations. The new stations are recording and available for improving water stage interpolation since July 2006. Neural network analysis has being used to provide an estimate of water stage at the new gage sites over the historic record (January 2000 to July 2006). Neural network analysis used static variables including percent prairie, percent sawgrass, percent upland, latitude, and longitude and dynamic water stage variables from existing gages surrounding the new location to predict stage at the new location. Details are provided in Conrads (2006). 
This estimate allows us to treat these locations as gaged sites over the entire record and improves interpolation of water stage surfaces for the historic record when the new gages were not actually established and collecting data.

The radial basis function interpolation is applied daily to daily median gage data in NAVD 88 composed of observed gage data, linearly interpolated "pseudo-gage data" along canals, and, prior to July 2006, hindcast gage data where new gages have since been established. Examples of spatially continuous interpolated water stage are shown in Figure 8.

Water depth is estimated when ground elevation from the EDEN DEM is subtracted from water stage as shown in Figure 9. Field observations of water depth have been compiled from numerous independent investigators and are continuing to be compiled. These data provide a comparison and validation of EDEN water depth results. Differences between EDEN modeled water depths and observed depths may be the result of (1) errors in the modeled water surface, (2) errors in the DEM, or (3) field measurement errors and different protocols among investigators. Particularly where differences are systematic over time and/or space, it may be possible to develop explanations that aid in producing improved depth estimations in the future. Water depth validation of EDEN interpolations prior to the addition of the new stations have been submitted for publication. Work on water depth estimation and comparisons to field observations is continuing and as new publications and information are released, they will be cited at http://sofia.usgs.gov/eden .

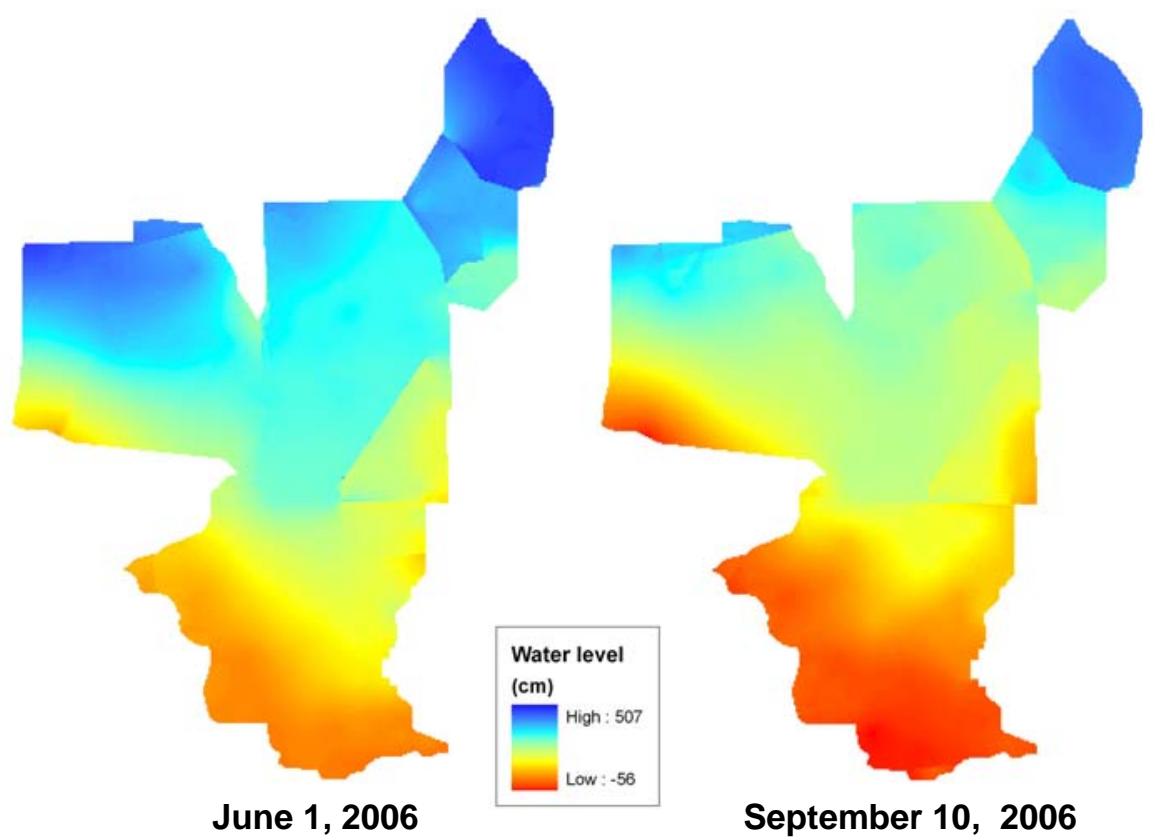

Figure 8. Water stage example from a wet season (left) and dry season (right) day. 


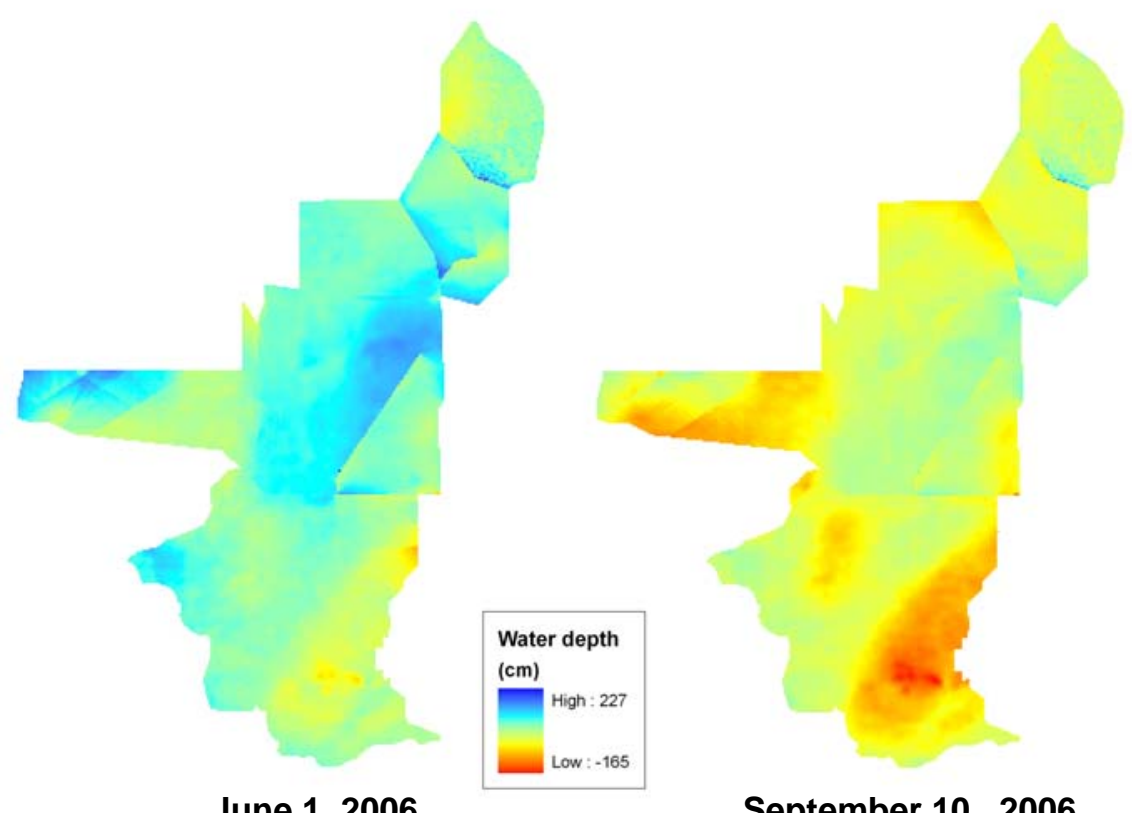

June 1, 2006

September 10, 2006

Figure 9. Water depth example from a wet season (left) and dry season (right) day.

\section{Confidence Index Maps}

A spatial confidence index map is created for each day in which a water stage is surfaced. The index gives a general indication of how much confidence can be assigned to the accuracy of any specific location on the surface. The confidence index is a geometric mean of three input layers: (1) distance from water stage gages, (2) distance from canals, and (3) cross-validation results for the generated surface. For distance from water stage gages, values range linearly from 1 (optimal) at the gage to 0 (no confidence) at $10 \mathrm{~km}$. Distance from canals is optimal when locations are at least $2 \mathrm{~km}$ from canals and approaches 0 as locations get nearer to a canal. Cross validation error computed by the radial basis function model for each station that had data on that day is applied to all the area closest to that station relative to all other stations (Thiessen polygon). The error represents the difference between measured and predicted water level for a station; the lower the error, the higher the confidence. Figure 10 illustrates improved confidence in the surfaced stage data layer when the new stations are included in the interpolation. Appendix $\mathrm{C}$ details the creation of confidence index maps in ArcGIS. 


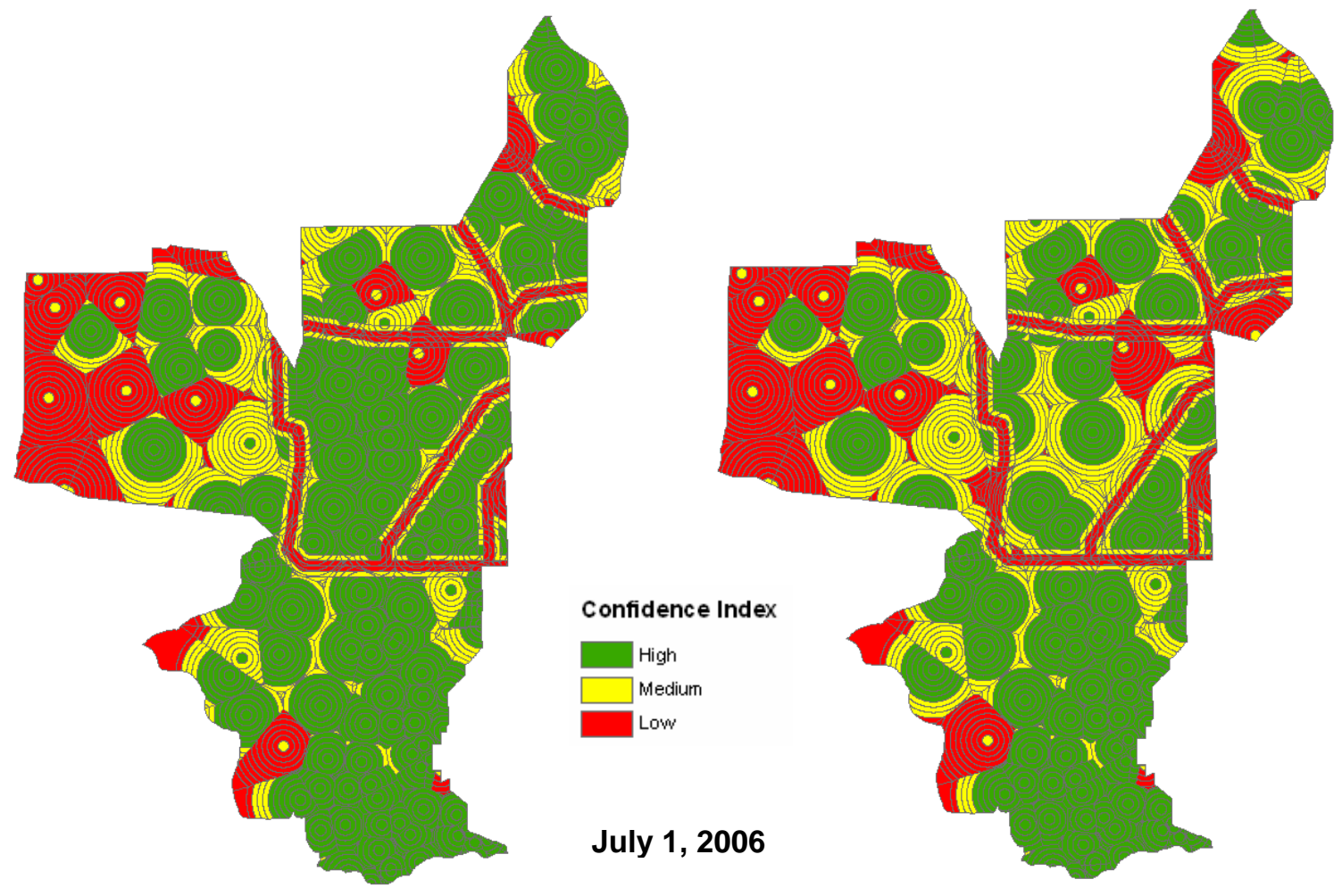

Figure 10. Confidence index maps for water stage surface developed with (left) and without (right) data at the new EDEN gaging stations.

\section{Discussion}

Two hundred and forty water level recorders provide the information for EDEN interpolations of daily water stage that provide spatially-explicit hydrologic predications necessary for modeling floral and faunal habitat suitability and distributions across the entire Everglades. These models are critical for evaluations of alternative Everglades restoration plans and monitoring of the habitat impacts of surface hydrologic dynamics. The interpolated surface covers the freshwater marsh and wetland forests of the Everglades system, however it does not attempt to predict surface water level in the coastal areas where stage is tide and wind-driven. It is anticipated that the SICS/TIME model (Wang et al. 2007) will be integrated with EDEN to provide stage surfaces along the coast in the future.

Sources of prediction errors may include model insufficiency, scale issues, density of stage gages, and proximity to abrupt changes in the surface (levees and canals). When independent observations of water stage or water depth are used for validation, differences in measurements methodologies between gage and field measurements can 
produce significant “apparent errors,” particularly for water depth measurements in the Everglades marsh communities. In the coming year, the EDEN project will be working with independent observers to increase our understanding of how these potential errors are partitioned.

The RBF method forces the interpolated continuous surface to pass exactly through observation points and therefore, the surface at gage locations precisely matches observations. The continuous surface is sampled to the $400 \mathrm{~m}$ grid by selecting the center elevation value as the value for the grid. If the location of interest is toward the edge of a grid, then the error introduced by gridding depends on the slope of the surface within the grid. Our observation is that the difference is usually within $1 \mathrm{~cm}$, however the difference is still to be documented. The RBF method mimics the smooth water surface between stations and it is our expectation that it is an accurate reflection of the real water surface. Confidence in the modeled surfaces has not been fully explored however, because of the lack of spatially independent water elevation data to be used for validation. Additional stage observations are becoming available however, particularly from studies by Dr. John Volin (Florida Atlantic University) in WCA3. Quantitative assessments of stage, slope of the water surface and water depth are possible and proceeding because of cooperative data-sharing by many Everglades researchers.

Scale is likely to be more of an issue in comparing our $400 \mathrm{~m}$ resolution predictions of water depth and field measurements (point measurements). Water surface typically varies gradually and smoothly and can usually be considered flat within a 400m grid. Ground surface, however, - and, therefore, water depth- is uneven and can easily change $20 \mathrm{~cm}$ as an observer moves from slough to emergent grass communities within the same grid cell. Since accuracy of hydrologic models is scale dependent (Wolock and Price 1994), selecting the appropriate spatial scale is important. Obeysekera and Rutchey (1997) examined effects of varied scale on loss of information in landscape modeling in the Everglades. Their study indicated that the area-perimeter relationship rapidly changes beyond the $100 \mathrm{~m}$ scale and important features nearly disappear beyond the $700 \mathrm{~m}$ scale. Although model scale as fine as $100 \mathrm{~m}$ or less may be optimal, such fine scale modeling of the entire greater Everglades is prohibitive. Proposed research to address this issue includes finer scale analysis of water depths stratified by vegetation within hydrologically similar clusters of smaller areas.

An additional source of errors is that many of the recording gages "bottom-out" when water recedes below ground or below the bottom of the recording equipment at the gage. The result is a false reading of water stage at the surface when it should be lower and pulls the interpolated water surface up around that gage. EDEN is negotiating installation of ground water level recorders associated with the gaging stations to solve this problem at some of the more critical stations.

Getting surfaced data into the hands of the user is also critical to the success of EDEN as a resource for restoration. Tools for easy assess to EDEN interpolated products have been and are being developed, including Web-based and PC-based interactive retrieval of data subsets over user-specified time periods, a utility for extracting 
interpolated data points at specific x,y locations and a profiling tool. Metadata describing the spatial referencing, creation date, and interpolation version of the surfaced datasets are embedded in the data files and daily cross-validation results are available for each water surface. As new data and new tools are made available, they will be posted to http://sofia.usgs.gov/eden .

\section{Acknowledgements}

The authors are grateful for the significant contributions of Pamela Telis, USGS, who coordinated the EDEN project team and reviewed this report. We also thank John Jones and Paul Conrads, USGS, for critical technical assistance and data analyses, and Roy Sonenshein and Heather Henkel for data management support.

The authors also thank Elmar Kurzbach, U.S. Army Corps of Engineers, and Ronnie Best, USGS Priority Ecosystem Science, for funding support and encouragement to the EDEN project. The Joint Ecosystems Modeling Laboratory at the University of Florida provided additional office and staff support.

Finally, thanks are extended to the Everglades researchers who tested and provided feedback of draft versions of results, suggested output formats for users, and shared their field observations. 


\section{References}

Barnhill, R.E., and Stead, S.E., 1984. Multistage trivariate surfaces, Rocky Mount. J. Math., 14, $103-118$.

Borga, M., and Vizzaccaro, A., 1997. On the interpolation of hydrologic variables, formal equivalence of multiquadric surface fitting and kriging. J of Hydrology, 195, 160171.

Carlson, R.E., and Foley, T.A., 1991. The parameter R2 in multiquadric interpolation. Comput. Math. Appl., 21, $29-42$.

Conrads, P.A. and Roehl, E.A., 2006. Estimating water depths using artificial neural networks. Hydroinformatics 2006, edited by Philippe Gourbesgille, Jean Cunge, Vincent Guinot, Shie-Yui Liong, Vol. 3, p. 1643-1650.

Conrads, P.A. and Roehl, E.A., (Unpublished). Hydrologic Record Extension of WaterLevel Data in the Florida Everglades, 2000-2006. U.S. Geological Survey OpenFile Report.

Curnutt, J. L., J. Comiskey, M. P. Nott, and L. J. Cross., 2000. Landscape-based spatially explicit species index models for Everglades restoration. Ecological Applications 10(6):1849-1860.

Dyn, N., and Levin, D., 1980. Bell shaped functions for surface fitting, Report 80-81, Dept. of Mathematical Science, Tel-Aviv University, Israel.

Dyn, N., and Levin, D., 1983. Iterative solution of systems originating from integral equations and surface interpolation, SIAM Jl Numer. Analysis 20, 377 - 390.

Ferreira, A.J.M., Roque, C.M.C., and Martins, P.A.L.S., 2005. Analysis of thin isotropic rectangular and circular plates with multiquadrics. Strength of Materials, 37 (2), 63-173.

Foley, T. A., 1987. Interpolation and approximation of 3-D and 4-D scattered data. Computers Math. Applic., 13, 711-740.

Franke. R., 1982. Scattered data interpolation: tests of some methods. Math. Comput. 38, $181-199$

Golberg, M.A., Chen, C.S., and Karur, S.R., 1996. Improved multiquadric approximation for partial differential equations. Engineering Analysis with boundary elements, 18, pp. 9-17. 
Gopfert, W., 1977. Interpolationsergebnisse mit der multiquadratischen Methode. ZfV Z. VermessWes. 102, 457 - 460. [With summary in English].

Hardy, R.L., 1971. Multiquadric equations of topography and irregular surfaces. J. Geophys. Res., 176(8), 1905-1915.

Hardy, R.L. 1977. Least squares prediction. Photogrammetric Engineering and Remote Sensing 43(4), 475-492.

Hardy, R.L., and Nelson, S.A., 1986. A multiquadric biharmonic representation and approximation of disturbing potential. Geoph. Res. Lett., 13, 18 - 21.

Hardy, R.L., 1988. Concepts and results of mapping in three dimensional space. Technical Papers, 2, 106 - 115. Cartography Am. Congr. Surveying And Mapping 48th A. Meet., St. Luis, Miss.

Hardy, R.L., 1990 Theory and applications of the multiquadric-biharmonic method, 20 years of Discovery, 1968 - 1988, Comp. math Applic. Vol 19, no. 8/9, pp. 163 208

Hardy, R.L., and Sirayanone, S., 1989. The multiquadric-biharmonic method of three dimentional mapping inside ore deposits. Proc. 1989 Multinat. Conf. Mine Planning and Design, Univ. of Kentucky, Lexington, KY, May 22-26, 1989.

Immanuel, A., Berry, M.W., Gross, L.J., Palmer, M. and Wang, D., 2005. A parallel implementation of ALFISH: simulating hydrological compartmentalization effects of fish dynamics in the Florida Everglades. Simulation Modeling Practice and Theory. 13:55-76.

Johnston, K., Ver Hoef, J.M., Krivoruchko, K., and Lucas, N., 2001. Using ArcGIS Geostatistical Analyst, ESRI Press, Redlands, California.

Jones, J.W. and Price, S.D., 2007a. Everglades Depth Estimation Network (EDEN) digital elevation model research and development. U.S. Geological Survey OpenFile Report 2007-1034, 29 pgs.

Jones, John W. and Price, Susan P. 2007b. Conceptual design of the Everglades Depth Estimation Network (EDEN) grid. U.S. Geological Survey Open File Report 2007-1200. 12 pgs.

Kansa, E.J., 1990a. Multiquadrics - a scattered data approximation scheme with applications to computational fluid-dynamics - I. Surface approximations and partial derivative estimates. Computers Math. Applic., 19 (8/9), 127 - 145. 
Kansa, E.J., 1990b. Multiquadrics - a scattered data approximation scheme with applications to computational fluid-dynamics - II. Solutions to parabolic, hyperbolic and elliptic partial differential equations. Computers Math. Applic., 19 (8/9), 147-161.

Kansa, E.J., and Carlson, R. E., 1992. Improved accuracy of multiquadric interpolation using variable shape parameters. Computers Math. Applic., 24 (12), 99-120.

Madych, W. R. and Nelson, S.A., 1990. Multivariate interpolation and conditionally positive definite functions. Mathematics and Computation, 54(189), 211-230.

Michelli, C. A., 1986. Interpolation of scattered data: distance matrices and conditionally positive functions. Constr. Approx., 2, pp. 11-22

Myers, D.E., 1994. Spatial interpolation: an overview. Geoderma, 62, 17 - 28.

Obeyselera, J., and Rutchey, K., 1997. Selection of scale for Everglades landscape models. Landscape Ecology, 12(1), 7-18.

Rippa, S., 1999. An algorithm for selecting a good value for the parameter c in radial basis function interpolation. Advances in Comp. Math., 11, pp. 193-210.

Sirayanone, S., 1988. Comparative studies of kriging, multiquadric-biharmonic, and other methods for solving mineral resource problems. PhD. Dissertation, Dept. of Earth Sciences, Iowa State University, Ames, Iowa.

Syed, K.H., Goodrich, D.C., Myers, D.E., and Sorooshiah, S., 2003. Spatial characteristics of thunderstorm rainfall fields and their relation to runoff. J. of Hydrology, 271, 1-21.

Telis, P.A., 2006. The Everglades Depth Estimation Network (EDEN) for support of ecological and biological assessments. U.S. Geological Survey Fact-Sheet 20063087, 4 p.

Walters, C., Gunderson, L. and Holling, C.S., 1992. Experimental policies for water management in the Everglades. Ecological Applications 2(2):189-202.

Wang, J.D., Swain, E.D., Wolfert, M.A., Langevin, C.D., James, D.E., and Telis, P.A., 2007, Application of FTLOADDS to Simulate Flow, Salinity, and Surface-Water Stage in the Southern Everglades, Florida: U.S. Geological Survey SIR 20075010, $112 \mathrm{p}$.

Wolock, D.M. and Price, C.V.,1994. Effects of digital elevation model map scale and data resolution on a topography-based watershed model. Water Resources Research 30(11):3041-3052. 


\section{Appendix A: Listing of EDEN water stage gaging stations}

EDEN water stage stations are listed below in two tables, separated by marsh gages and canal gages. Marsh gages include marsh, marsh structure and river gages. Canal gages include canal and canal structure. Canal and marsh indicate stations located in uncontrolled regions, canal structure indicates a station located within a canal at a structure, usually with an associated station on the other side of the structure, marsh structure indicates a station located in the marsh at a structure, usually with an associated station on the other side of the structure. In both cases, the associated station does not have to be of the same type (canal or marsh).

Geographic coordinates (Latitude, Longitude) are in NAD83 datum. UTM coordinates are zone $17 \mathrm{~N}$, NAD83, meters. EDEN-funded water level gaging stations are highlighted. Additional metadata for each station is provided at http://sofia.usgs.gov/eden .

Table A1. Marsh Stations sorted by location. (Note: Tidal gages in the Gulf of Mexico basin were not used in the surface water interpolation for the freshwater Everglades)

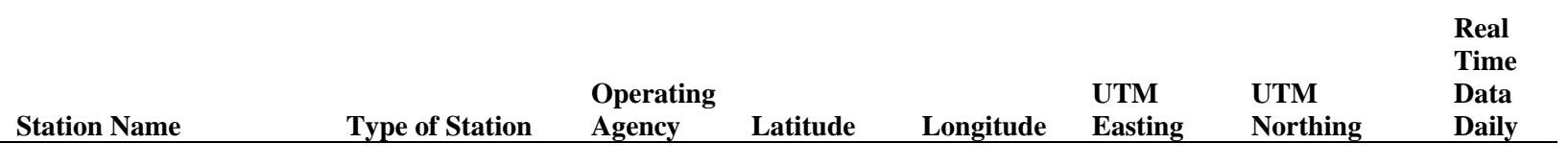

Big Cypress National Preserve

$\begin{array}{llll}\text { BCA1 } & \text { Marsh } & \text { BCNP } & 26^{\circ} 14^{\prime} 33^{\prime \prime} \\ \text { BCA10 } & \text { Marsh } & \text { BCNP } & 25^{\circ} 42^{\prime} 49^{\prime \prime} \\ \text { BCA11 } & \text { Marsh } & \text { BCNP } & 25^{\circ} 47^{\prime} 21^{\prime \prime} \\ \text { BCA12 } & \text { Marsh } & \text { BCNP } & 26^{\circ} 11^{\prime} 29^{\prime \prime} \\ \text { BCA13 } & \text { Marsh } & \text { BCNP } & 26^{\circ} 05^{\prime} 35^{\prime \prime} \\ \text { BCA14 } & \text { Marsh } & \text { BCNP } & 26^{\circ} 02^{\prime} 40^{\prime \prime} \\ \text { BCA15 } & \text { Marsh } & \text { SFWMD } & 26^{\circ} 02^{\prime} 23^{\prime \prime} \\ \text { BCA16 } & \text { Marsh } & \text { SFWMD } & 26^{\circ} 03^{\prime} 24^{\prime \prime} \\ \text { BCA17 } & \text { Marsh } & \text { SFWMD } & 26^{\circ} 12^{\prime} 18^{\prime \prime} \\ \text { BCA18 } & \text { Marsh } & \text { SFWMD } & 26^{\circ} 12^{\prime} 24^{\prime \prime} \\ \text { BCA19 } & \text { Marsh } & \text { SFWMD } & 25^{\circ} 47^{\prime} 35^{\prime \prime} \\ \text { BCA2 } & \text { Marsh } & \text { BCNP } & 26^{\circ} 11^{\prime} 46^{\prime \prime} \\ \text { BCA20 } & \text { Marsh } & \text { SFWMD } & 25^{\circ} 42^{\prime} 23^{\prime \prime} \\ \text { BCA3 } & \text { Marsh } & \text { BCNP } & 26^{\circ} 09^{\prime} 24^{\prime \prime} \\ \text { BCA4 } & \text { Marsh } & \text { BCNP } & 25^{\circ} 57^{\prime} 26^{\prime \prime} \\ \text { BCA5 } & \text { Marsh } & \text { BCNP } & 25^{\circ} 58^{\prime} 06^{\prime \prime} \\ \text { BCA6 } & \text { Marsh } & \text { BCNP } & 25^{\circ} 51^{\prime} 07^{\prime \prime} \\ \text { BCA7 } & \text { Marsh } & \text { BCNP } & 25^{\circ} 53^{\prime} 12^{\prime \prime} \\ \text { BCA8 } & \text { Marsh } & \text { BCNP } & 25^{\circ} 53^{\prime} 25^{\prime \prime} \\ \text { BCA9 } & \text { Marsh } & \text { BCNP } & 25^{\circ} 46^{\prime} 42^{\prime \prime} \\ \text { EDEN_1 } & \text { Marsh } & \text { USGS } & 25^{\circ} 51^{\prime} 38^{\prime \prime} \\ \text { EDEN_6 } & \text { Marsh } & \text { USGS } & 26^{\circ} 03^{\prime} 55^{\prime \prime} \\ \text { L28_GAP } & \text { Marsh } & \text { SFWMD } & 26^{\circ} 07^{\prime} 28^{\prime \prime} \\ \text { LOOP1_H } & \text { Marsh structure } & \text { SFWMD } & 25^{\circ} 45^{\prime} 41^{\prime \prime} \\ \text { LOOP1_T } & \text { Marsh structure } & \text { SFWMD } & 25^{\circ} 45^{\prime} 40^{\prime \prime} \\ \text { LOOP2_H } & \text { Marsh structure } & \text { SFWMD } & 25^{\circ} 44^{\prime} 48^{\prime \prime} \\ \text { LOOP2_T } & \text { Marsh structure } & \text { SFWMD } & 25^{\circ} 44^{\prime} 48^{\prime \prime} \\ \text { S344_T } & \text { Marsh structure } & \text { SFWMD } & 25^{\circ} 55^{\prime} 08^{\prime \prime}\end{array}$

$$
\begin{aligned}
& -81^{\circ} 19^{\prime} 14 " \\
& -81^{\circ} 01^{\prime} 19^{\prime \prime} \\
& -81^{\circ} 06^{\prime} 00^{\prime \prime} \\
& -81^{\circ} 05^{\prime} 12 " \\
& -81^{\circ} 03^{\prime} 13^{\prime \prime} \\
& -81^{\circ} 18^{\prime} 00^{\prime \prime} \\
& -81^{\circ} 01^{\prime} 36^{\prime \prime} \\
& -81^{\circ} 09^{\prime} 20^{\prime \prime} \\
& -81^{\circ} 10^{\prime} 05^{\prime \prime} \\
& -80^{\circ} 58^{\prime} 59^{\prime \prime} \\
& -81^{\circ} 12^{\prime} 08^{\prime \prime} \\
& -81^{\circ} 17^{\prime} 19^{\prime \prime} \\
& -80^{\circ} 56^{\prime} 05^{\prime \prime} \\
& -81^{\circ} 13^{\prime} 18^{\prime \prime} \\
& -81^{\circ} 06^{\prime} 14 " \\
& -80^{\circ} 55^{\prime} 35^{\prime \prime} \\
& -80^{\circ} 58^{\prime} 52^{\prime \prime} \\
& -81^{\circ} 15^{\prime} 44^{\prime \prime} \\
& -81^{\circ} 16^{\prime} 13^{\prime \prime} \\
& -80^{\circ} 54^{\prime} 44^{\prime \prime} \\
& -80^{\circ} 53^{\prime} 42^{\prime \prime} \\
& -80^{\circ} 54^{\prime} 14 " \\
& -80^{\circ} 59^{\prime} 00^{\prime \prime} \\
& -80^{\circ} 54^{\prime} 28^{\prime \prime} \\
& -80^{\circ} 54^{\prime} 28 " \\
& -80^{\circ} 57^{\prime} 14 " \\
& -80^{\circ} 57^{\prime} 15^{\prime \prime} \\
& -80^{\circ} 50^{\prime} 12^{\prime \prime}
\end{aligned}
$$

467985.6
497798.55
489974.43
491340.7
494638.96
469987.92
497325.26
484432.6
483203.49
501686.06
479719.22
471164.52
506542.12
477845.59
489599.28
507368.8
501892.72
473732.23
472926.09
508801.02
510514.97
509613.26
501659.44
509238.96
509241.26
504624.73
504601.42
516353.55

2902579.2 2843968.9 2852339.5 2896882.1 2885990.3 2880640.3 2880093.3 2881978.7 2898407 2898580.7 2852793.3 2897434.3 2843182.1 2893052.8 2870950.6 2872179 2859287.9 2863159.2 2863560.8 2851139 2860236.4 2882916.5 2889475.3 2849262.5 2849228.3 2847630.7 2847616.9 2866724.2
Yes
Yes
Yes
Yes
Yes
Yes
Yes
Yes
Yes
Yes
Yes
Yes
Yes
Yes
Yes
Yes
Yes
Yes
Yes
Yes
Yes
Yes
Yes
Yes
Yes
Yes
Yes
Yes 
Everglades National Park

\begin{tabular}{|c|c|}
\hline \multirow{2}{*}{$\begin{array}{l}\text { A13 } \\
\text { C111_wetland_east_of_F }\end{array}$} & \multirow[t]{2}{*}{ Marsh } \\
\hline & \\
\hline IU_LTER_TSPH5 & Marsh \\
\hline $\mathrm{CP}$ & Marsh \\
\hline CR2 & Marsh \\
\hline CR3 & Marsh \\
\hline CT27R & Marsh \\
\hline CT50R & Marsh \\
\hline CV5NR & Marsh \\
\hline CY2 & Marsh \\
\hline CY3 & Marsh \\
\hline DO1 & Marsh \\
\hline $\mathrm{DO} 2$ & Marsh \\
\hline E112 & Marsh \\
\hline E146 & Marsh \\
\hline EDEN_3 & Marsh \\
\hline EPSW & Marsh \\
\hline EVER4 & Marsh \\
\hline EVER6 & Marsh \\
\hline EVER7 & Marsh \\
\hline EVER8 & Marsh \\
\hline L31W & Marsh \\
\hline MET-1 & Marsh \\
\hline NCL & Marsh \\
\hline NE1 & Marsh \\
\hline NE2 & Marsh \\
\hline NE4 & Marsh \\
\hline NE5 & Marsh \\
\hline NESRS3 & Marsh \\
\hline NP201 & Marsh \\
\hline NP202 & Marsh \\
\hline NP203 & Marsh \\
\hline NP205 & Marsh \\
\hline NP206 & Marsh \\
\hline NP44 & Marsh \\
\hline NP46 & Marsh \\
\hline NP62 & Marsh \\
\hline NP67 & Marsh \\
\hline NP72 & Marsh \\
\hline NTS1 & Marsh \\
\hline NTS10 & Marsh \\
\hline NTS14 & Marsh \\
\hline NTS18 & Marsh \\
\hline OL & Marsh \\
\hline OT & Marsh \\
\hline P33 & Marsh \\
\hline P34 & Marsh \\
\hline P35 & Marsh \\
\hline P36 & Marsh \\
\hline P37 & Marsh \\
\hline P38 & Marsh \\
\hline R127 & Marsh \\
\hline R3110 & Marsh \\
\hline RG1 & Marsh \\
\hline RG2 & Marsh \\
\hline SP & Marsh \\
\hline $\begin{array}{l}\text { Taylor_Slough_wetland_ } \\
\text { at_E146 }\end{array}$ & Marsh \\
\hline TMC & Marsh \\
\hline TS2 & Marsh \\
\hline
\end{tabular}

\begin{tabular}{|c|c|c|c|c|c|}
\hline ENP & $25^{\circ} 29^{\prime} 50^{\prime \prime}$ & $-80^{\circ} 42^{\prime} 45^{\prime \prime}$ & 528887.43 & 2820049.8 & Yes \\
\hline USGS & $25^{\circ} 17^{\prime} 40^{\prime \prime}$ & $-80^{\circ} 31 ' 12 "$ & 548320.95 & 2797638.3 & Yes \\
\hline ENP & 2513'39" & $-80^{\circ} 42^{\prime} 14^{\prime \prime}$ & 529818.81 & 2790185.1 & Yes \\
\hline ENP & $25^{\circ} 29^{\prime} 55^{\prime \prime}$ & $-80^{\circ} 37^{\prime} 18^{\prime \prime}$ & 538016.06 & 2820226.4 & Yes \\
\hline ENP & $25^{\circ} 29^{\prime} 48^{\prime \prime}$ & $-80^{\circ} 39^{\prime} 46^{\prime \prime}$ & 533884.83 & 2820000 & Yes \\
\hline ENP & $25^{\circ} 18^{\prime} 03^{\prime \prime}$ & $-80^{\circ} 29^{\prime} 19^{\prime \prime}$ & 551472.28 & 2798370.4 & Yes \\
\hline ENP & $25^{\circ} 18^{\prime} 46^{\prime \prime}$ & $-80^{\circ} 31 ' 15^{\prime \prime}$ & 548223.82 & 2799681.1 & Yes \\
\hline ENP & $25^{\circ} 18^{\prime} 08^{\prime \prime}$ & $-80^{\circ} 29^{\prime} 15^{\prime \prime}$ & 551583.54 & 2798524.7 & Yes \\
\hline ENP & 2519'39" & $-80^{\circ} 40^{\prime} 58^{\prime \prime}$ & 531919.14 & 2801262.9 & Yes \\
\hline ENP & $25^{\circ} 19^{\prime} 40^{\prime \prime}$ & $-80^{\circ} 45^{\prime} 02^{\prime \prime}$ & 525097.66 & 2801279.3 & Yes \\
\hline ENP & $25^{\circ} 22^{\prime} 19^{\prime \prime}$ & $-80^{\circ} 41^{\prime} 27^{\prime \prime}$ & 531097.06 & 2806182.4 & Yes \\
\hline ENP & $25^{\circ} 23^{\prime} 18^{\prime \prime}$ & $-80^{\circ} 44^{\prime} 39^{\prime \prime}$ & 525727.88 & 2807985.9 & Yes \\
\hline ENP & $25^{\circ} 25^{\prime} 26^{\prime \prime}$ & $-80^{\circ} 36^{\prime} 35^{\prime \prime}$ & 539240.68 & 2811955.6 & Yes \\
\hline ENP & $25^{\circ} 15^{\prime} 13^{\prime \prime}$ & $-80^{\circ} 39^{\prime} 59^{\prime \prime}$ & 533588.89 & 2793085.2 & Yes \\
\hline USGS & $25^{\circ} 30^{\prime} 44^{\prime \prime}$ & $-80^{\circ} 55^{\prime} 59^{\prime \prime}$ & 506727.07 & 2821669 & Yes \\
\hline ENP & $25^{\circ} 16^{\prime} 17^{\prime \prime}$ & $-80^{\circ} 30^{\prime} 29^{\prime \prime}$ & 549526.79 & 2795102.7 & Yes \\
\hline USGS & $25^{\circ} 20^{\prime} 37^{\prime \prime}$ & $-80^{\circ} 32^{\prime} 42^{\prime \prime}$ & 545779.69 & 2803086.9 & Yes \\
\hline ENP & $25^{\circ} 17^{\prime} 49^{\prime \prime}$ & $-80^{\circ} 30^{\prime} 41^{\prime \prime}$ & 549180.86 & 2797931.3 & Yes \\
\hline ENP & 2518'31" & $-80^{\circ} 32^{\prime} 32^{\prime \prime}$ & 546072.44 & 2799212.2 & Yes \\
\hline ENP & $25^{\circ} 20^{\prime} 42^{\prime \prime}$ & $-80^{\circ} 28^{\prime} 42^{\prime \prime}$ & 552487.9 & 2803265.1 & Yes \\
\hline ENP & $25^{\circ} 26^{\prime} 13^{\prime \prime}$ & $-80^{\circ} 35^{\prime} 23^{\prime \prime}$ & 541247.55 & 2813407.3 & Yes \\
\hline USGS & $25^{\circ} 43^{\prime} 13^{\prime \prime}$ & $-80^{\circ} 35^{\prime} 18^{\prime \prime}$ & 541300.2 & 2844777.7 & Yes \\
\hline ENP & 25¹4'33" & $-80^{\circ} 44^{\prime} 40^{\prime \prime}$ & 525730.64 & 2791837.7 & Yes \\
\hline USGS & $25^{\circ} 41 ' 31^{\prime \prime}$ & $-80^{\circ} 38^{\prime} 04^{\prime \prime}$ & 536672.92 & 2841631.5 & Yes \\
\hline USGS & $25^{\circ} 43^{\prime} 16^{\prime \prime}$ & -80³3'14" & 544745.08 & 2844886.2 & Yes \\
\hline USGS & $25^{\circ} 38^{\prime} 29^{\prime \prime}$ & $-80^{\circ} 39^{\prime} 10^{\prime \prime}$ & 534848.01 & 2836028.3 & Yes \\
\hline USGS & 253'ㄴ' & $-80^{\circ} 39^{\prime} 35^{\prime \prime}$ & 534153.67 & 2834949.9 & Yes \\
\hline SFWMD & $25^{\circ} 44^{\prime} 26^{\prime \prime}$ & $-80^{\circ} 30^{\prime} 16^{\prime \prime}$ & 549697.14 & 2847057.1 & No \\
\hline ENP & $25^{\circ} 43^{\prime} 00^{\prime \prime}$ & $-80^{\circ} 43^{\prime} 10^{\prime \prime}$ & 528138.14 & 2844348.3 & Yes \\
\hline ENP & $25^{\circ} 39^{\prime} 43^{\prime \prime}$ & $-80^{\circ} 42^{\prime} 31^{\prime \prime}$ & 529238.28 & 2838291 & Yes \\
\hline ENP & 253'ㄹ" & $-80^{\circ} 44^{\prime} 19^{\prime \prime}$ & 526235.86 & 2833947.6 & Yes \\
\hline ENP & $25^{\circ} 41^{\prime} 19^{\prime \prime}$ & $-80^{\circ} 50^{\prime} 52^{\prime \prime}$ & 515267.35 & 2841220.6 & Yes \\
\hline ENP & 2532'39" & $-80^{\circ} 40^{\prime} 19^{\prime \prime}$ & 532950.59 & 2825257.5 & Yes \\
\hline ENP & $25^{\circ} 26^{\prime} 00^{\prime \prime}$ & $-80^{\circ} 43^{\prime} 13^{\prime \prime}$ & 528120.54 & 2812973.6 & Yes \\
\hline ENP & 2519'06" & $-80^{\circ} 47^{\prime} 45^{\prime \prime}$ & 520542.31 & 2800225.8 & Yes \\
\hline ENP & $25^{\circ} 26^{\prime} 18^{\prime \prime}$ & $-80^{\circ} 46^{\prime} 58^{\prime \prime}$ & 521834.87 & 2813515.6 & Yes \\
\hline ENP & $25^{\circ} 19^{\prime} 46^{\prime \prime}$ & $-80^{\circ} 39^{\prime} 01^{\prime \prime}$ & 535189.52 & 2801486.4 & Yes \\
\hline ENP & $25^{\circ} 23^{\prime} 41^{\prime \prime}$ & $-80^{\circ} 42^{\prime} 11^{\prime \prime}$ & 529861.83 & 2808701.8 & Yes \\
\hline ENP & $25^{\circ} 26^{\prime} 12^{\prime \prime}$ & -80³5'34" & 540940.39 & 2813375.6 & Yes \\
\hline ENP & $25^{\circ} 27^{\prime} 37^{\prime \prime}$ & $-80^{\circ} 36^{\prime} 18^{\prime \prime}$ & 539703.67 & 2815986.5 & Yes \\
\hline ENP & $25^{\circ} 24^{\prime} 59^{\prime \prime}$ & $-80^{\circ} 38^{\prime} 19^{\prime \prime}$ & 536337.73 & 2811117 & Yes \\
\hline ENP & $25^{\circ} 29^{\prime} 02^{\prime \prime}$ & $-80^{\circ} 33^{\prime} 59^{\prime \prime}$ & 543576.93 & 2818613.1 & Yes \\
\hline ENP & $25^{\circ} 15^{\prime} 49^{\prime \prime}$ & $-80^{\circ} 36^{\prime} 47^{\prime \prime}$ & 538956.66 & 2794206.9 & Yes \\
\hline ENP & $25^{\circ} 34^{\prime} 43^{\prime \prime}$ & $-80^{\circ} 57^{\prime} 52^{\prime \prime}$ & 503563.89 & 2829031.6 & Yes \\
\hline ENP & $25^{\circ} 36^{\prime} 50^{\prime \prime}$ & $-80^{\circ} 42^{\prime} 08^{\prime \prime}$ & 529891.45 & 2832971 & Yes \\
\hline ENP & $25^{\circ} 36^{\prime} 27^{\prime \prime}$ & $-80^{\circ} 56^{\prime} 27^{\prime \prime}$ & 505933.85 & 2832231.4 & Yes \\
\hline ENP & $25^{\circ} 27^{\prime} 35^{\prime \prime}$ & $-80^{\circ} 51^{\prime} 52^{\prime \prime}$ & 513620.73 & 2815873.2 & Yes \\
\hline ENP & 2531'38" & $-80^{\circ} 47^{\prime} 44^{\prime \prime}$ & 520534.99 & 2823356.4 & Yes \\
\hline ENP & $25^{\circ} 17^{\prime} 03^{\prime \prime}$ & $-80^{\circ} 41^{\prime} 18^{\prime \prime}$ & 531371.13 & 2796463.3 & Yes \\
\hline ENP & $25^{\circ} 22^{\prime} 10^{\prime \prime}$ & $-80^{\circ} 50^{\prime} 00^{\prime \prime}$ & 516760.87 & 2805880.2 & Yes \\
\hline ENP & $25^{\circ} 21^{\prime} 11^{\prime \prime}$ & $-80^{\circ} 36^{\prime} 22^{\prime \prime}$ & 539626.91 & 2804113.2 & Yes \\
\hline ENP & $25^{\circ} 26^{\prime} 46^{\prime \prime}$ & $-80^{\circ} 37^{\prime} 34^{\prime \prime}$ & 537585.66 & 2814411.6 & Yes \\
\hline ENP & $25^{\circ} 34^{\prime} 53^{\prime \prime}$ & $-80^{\circ} 36^{\prime} 28^{\prime \prime}$ & 539384.9 & 2829396.8 & Yes \\
\hline ENP & 253'ㄱ" & $-80^{\circ} 36^{\prime} 21^{\prime \prime}$ & 539592.96 & 2825091 & Yes \\
\hline ENP & 2523'19" & $-80^{\circ} 47^{\prime} 50^{\prime \prime}$ & 520390.78 & 2808007.5 & Yes \\
\hline USGS & $25^{\circ} 14^{\prime} 57^{\prime \prime}$ & $-80^{\circ} 39^{\prime} 58^{\prime \prime}$ & 533624.49 & 2792579.9 & Yes \\
\hline ENP & $25^{\circ} 36^{\prime} 50^{\prime \prime}$ & $-80^{\circ} 52^{\prime} 20^{\prime \prime}$ & 512822.47 & 2832943.7 & Yes \\
\hline ENP & $25^{\circ} 24^{\prime} 00^{\prime \prime}$ & $-80^{\circ} 36^{\prime} 24^{\prime \prime}$ & 539555.74 & 2809311.3 & Yes \\
\hline
\end{tabular}




\begin{tabular}{|c|c|c|c|c|c|c|c|}
\hline $\mathrm{TSH}$ & Marsh & ENP & $25^{\circ} 18^{\prime} 39^{\prime \prime}$ & $-80^{\circ} 37^{\prime} 50^{\prime \prime}$ & 537180.09 & 2799430.9 & Yes \\
\hline S12A_T & Marsh structure & USGS & $25^{\circ} 45^{\prime} 41^{\prime \prime}$ & $-80^{\circ} 49^{\prime} 16^{\prime \prime}$ & 517941.2 & 2849281.2 & Yes \\
\hline S12B_T & Marsh structure & USGS & $25^{\circ} 45^{\prime} 42^{\prime \prime}$ & $-80^{\circ} 46^{\prime} 10^{\prime \prime}$ & 523113.3 & 2849299.6 & Yes \\
\hline S12C_T & Marsh structure & USGS & $25^{\circ} 45^{\prime} 42^{\prime \prime}$ & $-80^{\circ} 43^{\prime} 37^{\prime \prime}$ & 527381.63 & 2849310.3 & Yes \\
\hline S12D_T & Marsh structure & USGS & $25^{\circ} 45^{\prime} 42^{\prime \prime}$ & $-80^{\circ} 40^{\prime} 55^{\prime \prime}$ & 531907.94 & 2849325.5 & Yes \\
\hline S332B_T & Marsh structure & SFWMD & $25^{\circ} 32^{\prime} 58^{\prime \prime}$ & $-80^{\circ} 33^{\prime} 38^{\prime \prime}$ & 544138.76 & 2825874.6 & Yes \\
\hline S332_T & Marsh structure & SFWMD & $25^{\circ} 25^{\prime} 19^{\prime \prime}$ & $-80^{\circ} 35^{\prime} 26^{\prime \prime}$ & 541180 & 2811722.3 & Yes \\
\hline \multicolumn{8}{|c|}{ Water Conservation Area 1} \\
\hline NORTH_CA1 & Marsh & USGS & $26^{\circ} 35^{\prime} 38^{\prime \prime}$ & $-80^{\circ} 21 ' 13^{\prime \prime}$ & 564356.19 & 2941626.1 & Yes \\
\hline SITE_7 & Marsh & USGS & $26^{\circ} 31^{\prime} 11^{\prime \prime}$ & $-80^{\circ} 20^{\prime} 49^{\prime \prime}$ & 565061.88 & 2933415.4 & Yes \\
\hline SITE_8C & Marsh & USGS & $26^{\circ} 30^{\prime} 01^{\prime \prime}$ & $-80^{\circ} 13^{\prime} 21^{\prime \prime}$ & 577474.8 & 2931309.2 & Yes \\
\hline SITE_8T & Marsh & USGS & $26^{\circ} 29^{\prime} 59^{\prime \prime}$ & $-80^{\circ} 14^{\prime} 05^{\prime \prime}$ & 576266.93 & 2931241.7 & Yes \\
\hline SITE_9 & Marsh & USGS & $26^{\circ} 27^{\prime} 51^{\prime \prime}$ & $-80^{\circ} 17^{\prime} 49^{\prime \prime}$ & 570077.53 & 2927288.8 & Yes \\
\hline SOUTH_CA1 & Marsh & USGS & $26^{\circ} 25^{\prime} 29^{\prime \prime}$ & $-80^{\circ} 20^{\prime} 26^{\prime \prime}$ & 565752.41 & 2922897.3 & Yes \\
\hline WCA1ME & Marsh & SFWMD & $26^{\circ} 30^{\prime} 39^{\prime \prime}$ & $-80^{\circ} 18^{\prime} 36^{\prime \prime}$ & 568748.31 & 2932450.2 & Yes \\
\hline \multicolumn{8}{|c|}{ Water Conservation Area 2A } \\
\hline $2 \mathrm{~A} 300$ & Marsh & SFWMD & $26^{\circ} 14^{\prime} 47^{\prime \prime}$ & $-80^{\circ} 24 ' 29^{\prime \prime}$ & 559111.67 & 2903114.4 & No \\
\hline EDEN_11 & Marsh & USGS & $26^{\circ} 22^{\prime} 35^{\prime \prime}$ & $-80^{\circ} 27^{\prime} 19^{\prime \prime}$ & 553893.8 & 2918188.1 & Yes \\
\hline SITE_17 & Marsh & USGS & $26^{\circ} 17^{\prime} 12^{\prime \prime}$ & $-80^{\circ} 24 ' 39^{\prime \prime}$ & 558813.97 & 2907573.8 & Yes \\
\hline SITE_19 & Marsh & USGS & $26^{\circ} 16^{\prime} 56^{\prime \prime}$ & $-80^{\circ} 18^{\prime} 22^{\prime \prime}$ & 569272.04 & 2907133.4 & Yes \\
\hline WCĀ2E1 & Marsh & SFWMD & $26^{\circ} 21^{\prime} 07^{\prime \prime}$ & $-80^{\circ} 21^{\prime} 10^{\prime \prime}$ & 564574.02 & 2914831 & No \\
\hline WCA2E4 & Marsh & SFWMD & $26^{\circ} 18^{\prime} 35^{\prime \prime}$ & $-80^{\circ} 21 ' 23^{\prime \prime}$ & 564236.97 & 2910153.1 & No \\
\hline WCA2F1 & Marsh & SFWMD & $26^{\circ} 21^{\prime} 36^{\prime \prime}$ & $-80^{\circ} 22^{\prime} 11^{\prime \prime}$ & 562878.89 & 2915714.7 & No \\
\hline WCA2F4 & Marsh & SFWMD & $26^{\circ} 19^{\prime} 02^{\prime \prime}$ & $-80^{\circ} 23^{\prime} 05^{\prime \prime}$ & 561404.79 & 2910969.9 & No \\
\hline WCA2RT & Marsh & SFWMD & $26^{\circ} 19^{\prime} 48^{\prime \prime}$ & $-80^{\circ} 30^{\prime} 35^{\prime \prime}$ & 548922.85 & 2912331.7 & No \\
\hline WCA2U1 & Marsh & SFWMD & $26^{\circ} 14^{\prime} 29^{\prime \prime}$ & $-80^{\circ} 21 ' 21 "$ & 564330.06 & 2902585.6 & No \\
\hline WCA2U3 & Marsh & SFWMD & $26^{\circ} 17^{\prime} 17^{\prime \prime}$ & $-80^{\circ} 24 ' 39^{\prime \prime}$ & 558813.27 & 2907727.6 & No \\
\hline S10A_T & Marsh structure & USGS & $26^{\circ} 21^{\prime} 33^{\prime \prime}$ & $-80^{\circ} 18^{\prime} 46^{\prime \prime}$ & 568563.45 & 2915633.1 & Yes \\
\hline S10C_T & Marsh structure & USGS & $26^{\circ} 22^{\prime} 16^{\prime \prime}$ & $-80^{\circ} 21^{\prime} 09^{\prime \prime}$ & 564583.86 & 2916948 & Yes \\
\hline S10D_T & Marsh structure & USGS & $26^{\circ} 23^{\prime} 18^{\prime \prime}$ & $-80^{\circ} 22^{\prime} 55^{\prime \prime}$ & 561635.81 & 2918827.9 & Yes \\
\hline S11A_H & Marsh structure & USGS & $26^{\circ} 10^{\prime} 37^{\prime \prime}$ & $-80^{\circ} 26^{\prime} 54^{\prime \prime}$ & 555115.46 & 2895405.3 & Yes \\
\hline S11B_H & Marsh structure & USGS & $26^{\circ} 12^{\prime} 09^{\prime \prime}$ & $-80^{\circ} 27^{\prime} 14^{\prime \prime}$ & 554557.92 & 2898235.2 & Yes \\
\hline S11C_H & Marsh structure & USGS & $26^{\circ} 13^{\prime} 47^{\prime \prime}$ & $-80^{\circ} 27^{\prime} 35^{\prime \prime}$ & 553950.86 & 2901225.2 & Yes \\
\hline S144_H & Marsh structure & SFWMD & $26^{\circ} 13^{\prime} 06^{\prime \prime}$ & $-80^{\circ} 23^{\prime} 52^{\prime \prime}$ & 560158.68 & 2900008.9 & No \\
\hline S145_H & Marsh structure & SFWMD & $26^{\circ} 13^{\prime} 19^{\prime \prime}$ & $-80^{\circ} 21^{\prime} 57^{\prime \prime}$ & 563348.91 & 2900416.9 & No \\
\hline S146_H & Marsh structure & SFWMD & $26^{\circ} 13^{\prime} 32^{\prime \prime}$ & $-80^{\circ} 20^{\prime} 01^{\prime \prime}$ & 566576.24 & 2900838.9 & No \\
\hline \multicolumn{8}{|c|}{ Water Conservation Area 2B } \\
\hline EDEN_13 & Marsh & USGS & $26^{\circ} 10^{\prime} 35^{\prime \prime}$ & $-80^{\circ} 22^{\prime} 17^{\prime \prime}$ & 562816.46 & 2895370 & Yes \\
\hline SITE_99 & Marsh & USGS & $26^{\circ} 08^{\prime} 14^{\prime \prime}$ & $-80^{\circ} 22^{\prime} 01^{\prime \prime}$ & 563276.53 & 2891044 & Yes \\
\hline S141_H & Marsh structure & SFWMD & $26^{\circ} 09^{\prime} 02^{\prime \prime}$ & $-80^{\circ} 26^{\prime} 32^{\prime \prime}$ & 555755.44 & 2892486.9 & No \\
\hline S144_T & Marsh structure & SFWMD & $26^{\circ} 13^{\prime} 05^{\prime \prime}$ & $-80^{\circ} 23^{\prime} 52^{\prime \prime}$ & 560164.6 & 2899975.5 & No \\
\hline S145_T & Marsh structure & SFWMD & $26^{\circ} 13^{\prime} 18^{\prime \prime}$ & $-80^{\circ} 21^{\prime} 57^{\prime \prime}$ & 563352.07 & 2900385.7 & No \\
\hline S146_T & Marsh structure & SFWMD & $26^{\circ} 13^{\prime} 31^{\prime \prime}$ & $-80^{\circ} 20^{\prime} 00^{\prime \prime}$ & 566581.41 & 2900799.4 & No \\
\hline \multicolumn{8}{|c|}{ Water Conservation Area 3A } \\
\hline 3A10 & Marsh & SFWMD & $26^{\circ} 16^{\prime} 46^{\prime \prime}$ & $-80^{\circ} 44 ' 23^{\prime \prime}$ & 525980.05 & 2906666.3 & No \\
\hline 3A11 & Marsh & SFWMD & $26^{\circ} 13^{\prime} 06^{\prime \prime}$ & $-80^{\circ} 44^{\prime} 37^{\prime \prime}$ & 525605.14 & 2899897.8 & No \\
\hline 3A12 & Marsh & SFWMD & $26^{\circ} 10^{\prime} 09^{\prime \prime}$ & $-80^{\circ} 40^{\prime} 32^{\prime \prime}$ & 532417.15 & 2894468.1 & No \\
\hline $3 A-5$ & Marsh & USGS & $26^{\circ} 03^{\prime} 24^{\prime \prime}$ & $-80^{\circ} 42^{\prime} 19^{\prime \prime}$ & 529481.03 & 2881992.6 & Yes \\
\hline 3A9 & Marsh & SFWMD & $26^{\circ} 07^{\prime} 23^{\prime \prime}$ & $-80^{\circ} 38^{\prime} 51^{\prime \prime}$ & 535234.78 & 2889368.9 & No \\
\hline 3AN1W1 & Marsh & SFWMD & $26^{\circ} 11^{\prime} 17^{\prime \prime}$ & $-80^{\circ} 44^{\prime} 24^{\prime \prime}$ & 525972.58 & 2896545.5 & Yes \\
\hline 3ANE & Marsh & SFWMD & $26^{\circ} 16^{\prime} 44^{\prime \prime}$ & $-80^{\circ} 36^{\prime} 17^{\prime \prime}$ & 539459.07 & 2906638.9 & Yes \\
\hline 3ANW & Marsh & SFWMD & $26^{\circ} 17^{\prime} 09^{\prime \prime}$ & $-80^{\circ} 46^{\prime} 32^{\prime \prime}$ & 522401.12 & 2907367.1 & Yes \\
\hline 3AS & Marsh & SFWMD & $26^{\circ} 05^{\prime} 01^{\prime \prime}$ & $-80^{\circ} 41^{\prime} 03^{\prime \prime}$ & 531579.54 & 2884991.4 & Yes \\
\hline 3AS3W1 & Marsh & SFWMD & $25^{\circ} 51^{\prime} 27^{\prime \prime}$ & $-80^{\circ} 46^{\prime} 15^{\prime \prime}$ & 522955.75 & 2859933.8 & Yes \\
\hline 3ASW & Marsh & SFWMD & 255'ㄹ' & $-80^{\circ} 50^{\prime} 09^{\prime \prime}$ & 516424.38 & 2874597 & Yes \\
\hline EDEN_12 & Marsh & USGS & $26^{\circ} 00^{\prime} 42^{\prime \prime}$ & $-80^{\circ} 35^{\prime} 17^{\prime \prime}$ & 541222.59 & 2877040.8 & Yes \\
\hline EDEN_14 & Marsh & USGS & $26^{\circ} 04^{\prime} 10^{\prime \prime}$ & $-80^{\circ} 45^{\prime} 27^{\prime \prime}$ & 524254.59 & 2883397 & Yes \\
\hline EDEN_4 & Marsh & USGS & $26^{\circ} 05^{\prime} 36^{\prime \prime}$ & $-80^{\circ} 30^{\prime} 25^{\prime \prime}$ & 549305.17 & 2886113.3 & Yes \\
\hline EDEN_5 & Marsh & USGS & $26^{\circ} 07^{\prime} 25^{\prime \prime}$ & $-80^{\circ} 45^{\prime} 10^{\prime \prime}$ & 524715.52 & 2889396.6 & Yes \\
\hline EDEN_8 & Marsh & USGS & $25^{\circ} 52^{\prime} 00^{\prime \prime}$ & $-80^{\circ} 40^{\prime} 50^{\prime \prime}$ & 532005.36 & 2860957.1 & Yes \\
\hline EDEN_9 & Marsh & USGS & $26^{\circ} 13^{\prime} 19^{\prime \prime}$ & $-80^{\circ} 35^{\prime} 32^{\prime \prime}$ & 540732.67 & 2900327.2 & Yes \\
\hline
\end{tabular}




\begin{tabular}{|c|c|c|c|c|c|c|c|}
\hline SITE_62 & Marsh & USGS & $26^{\circ} 10^{\prime} 29^{\prime \prime}$ & $-80^{\circ} 45^{\prime} 04^{\prime \prime}$ & 524865.17 & 2895066.7 & Yes \\
\hline SITE_63 & Marsh & USGS & $26^{\circ} 11^{\prime} 20^{\prime \prime}$ & $-80^{\circ} 31^{\prime} 51^{\prime \prime}$ & 546872.5 & 2896696.4 & Yes \\
\hline SITE_64 & Marsh & USGS & $25^{\circ} 58^{\prime} 32^{\prime \prime}$ & $-80^{\circ} 40^{\prime} 09^{\prime \prime}$ & 533109.96 & 2873028.9 & Yes \\
\hline SITE_65 & Marsh & USGS & 254'53" & $-80^{\circ} 43^{\prime} 11^{\prime \prime}$ & 528087.23 & 2855206.6 & Yes \\
\hline W11 & Marsh & USGS & $25^{\circ} 56^{\prime} 34^{\prime \prime}$ & $-80^{\circ} 45^{\prime} 00^{\prime \prime}$ & 525031.57 & 2869370.8 & Yes \\
\hline W14 & Marsh & USGS & $25^{\circ} 56^{\prime} 14^{\prime \prime}$ & $-80^{\circ} 40^{\prime} 06^{\prime \prime}$ & 533210.16 & 2868773.7 & Yes \\
\hline W15 & Marsh & USGS & $26^{\circ} 00^{\prime} 51^{\prime \prime}$ & $-80^{\circ} 40^{\prime} 40^{\prime \prime}$ & 532243.48 & 2877292.5 & Yes \\
\hline W18 & Marsh & USGS & $26^{\circ} 00^{\prime} 07^{\prime \prime}$ & $-80^{\circ} 46^{\prime} 44^{\prime \prime}$ & 522127.95 & 2875917.9 & Yes \\
\hline W2 & Marsh & USGS & $25^{\circ} 47^{\prime} 59^{\prime \prime}$ & $-80^{\circ} 48^{\prime} 32^{\prime \prime}$ & 519158.29 & 2853518.6 & Yes \\
\hline W5 & Marsh & USGS & $25^{\circ} 47^{\prime} 21^{\prime \prime}$ & $-80^{\circ} 41^{\prime} 43^{\prime \prime}$ & 530550.21 & 2852371.1 & Yes \\
\hline S11A_T & Marsh structure & USGS & $26^{\circ} 10^{\prime} 37^{\prime \prime}$ & $-80^{\circ} 26^{\prime} 57^{\prime \prime}$ & 555030.78 & 2895390.9 & Yes \\
\hline S11B_T & Marsh structure & USGS & $26^{\circ} 12^{\prime} 09^{\prime \prime}$ & $-80^{\circ} 27^{\prime} 18^{\prime \prime}$ & 554456.55 & 2898221.3 & Yes \\
\hline S11C_T & Marsh structure & USGS & $26^{\circ} 13^{\prime} 46^{\prime \prime}$ & $-80^{\circ} 27^{\prime} 39^{\prime \prime}$ & 553853.05 & 2901210.4 & Yes \\
\hline S142_T & Marsh structure & SFWMD & $26^{\circ} 09^{\prime} 36^{\prime \prime}$ & $-80^{\circ} 26^{\prime} 47^{\prime \prime}$ & 555326.93 & 2893522.7 & No \\
\hline S150_T & Marsh structure & SFWMD & $26^{\circ} 20^{\prime} 05^{\prime \prime}$ & $-80^{\circ} 32^{\prime} 22^{\prime \prime}$ & 545964.12 & 2912820.6 & Yes \\
\hline S150_T & Marsh structure & USGS & $26^{\circ} 20^{\prime} 05^{\prime \prime}$ & $-80^{\circ} 32 ' 22^{\prime \prime}$ & 545964.12 & 2912820.6 & No \\
\hline S343A_H & Marsh structure & SFWMD & $25^{\circ} 47^{\prime} 21^{\prime \prime}$ & $-80^{\circ} 51^{\prime} 19^{\prime \prime}$ & 514522.22 & 2852358.7 & Yes \\
\hline S343B_H & Marsh structure & SFWMD & $25^{\circ} 46^{\prime} 42^{\prime \prime}$ & $-80^{\circ} 50^{\prime} 38^{\prime \prime}$ & 515652.05 & 2851135.3 & Yes \\
\hline S344_H & Marsh structure & SFWMD & $25^{\circ} 55^{\prime} 08^{\prime \prime}$ & $-80^{\circ} 50^{\prime} 11^{\prime \prime}$ & 516395.18 & 2866714.4 & Yes \\
\hline \multicolumn{8}{|l|}{ Water Conservation Area 3B } \\
\hline 3BS1W1 & Marsh & SFWMD & $25^{\circ} 46^{\prime} 50^{\prime \prime}$ & $-80^{\circ} 30^{\prime} 40^{\prime \prime}$ & 549012.05 & 2851484.1 & Yes \\
\hline 3B-SE & Marsh & SFWMD & $25^{\circ} 47^{\prime} 17^{\prime \prime}$ & $-80^{\circ} 29^{\prime} 58^{\prime \prime}$ & 550178.69 & 2852319 & No \\
\hline EDEN_7 & Marsh & USGS & $25^{\circ} 57^{\prime} 08^{\prime \prime}$ & $-80^{\circ} 29^{\prime} 55^{\prime \prime}$ & 550198.51 & 2870488.9 & Yes \\
\hline EDEN_10 & Marsh & USGS & $25^{\circ} 47^{\prime} 07^{\prime \prime}$ & $-80^{\circ} 37^{\prime} 02^{\prime \prime}$ & 538377.06 & 2851960.8 & Yes \\
\hline SITE_69 & Marsh & USGS & $25^{\circ} 54^{\prime} 24^{\prime \prime}$ & $-80^{\circ} 35^{\prime} 20^{\prime \prime}$ & 541208.91 & 2865450.1 & Yes \\
\hline SITE_71 & Marsh & USGS & $25^{\circ} 53^{\prime} 05^{\prime \prime}$ & $-80^{\circ} 33^{\prime} 24^{\prime \prime}$ & 544405.47 & 2863003.3 & Yes \\
\hline SITE_76 & Marsh & USGS & $26^{\circ} 00^{\prime} 28^{\prime \prime}$ & $-80^{\circ} 28^{\prime} 57^{\prime \prime}$ & 551781.68 & 2876657.8 & Yes \\
\hline SRS1 & Marsh & USGS & $25^{\circ} 47^{\prime} 55^{\prime \prime}$ & $-80^{\circ} 34 ' 42^{\prime \prime}$ & 542265.46 & 2853460.3 & Yes \\
\hline TI-8 & Marsh & USGS & $25^{\circ} 49^{\prime} 57^{\prime \prime}$ & $-80^{\circ} 32^{\prime} 28^{\prime \prime}$ & 545989.77 & 2857214.7 & Yes \\
\hline TI-9 & Marsh & USGS & $25^{\circ} 50^{\prime} 14^{\prime \prime}$ & $-80^{\circ} 35^{\prime} 58^{\prime \prime}$ & 540141.95 & 2857718.6 & Yes \\
\hline S9A_T & Marsh structure & SFWMD & $26^{\circ} 03^{\prime} 41^{\prime \prime}$ & $-80^{\circ} 26^{\prime} 38^{\prime \prime}$ & 555630.46 & 2882614.6 & Yes \\
\hline \multicolumn{8}{|l|}{ Florida Bay (Tidal Rivers) } \\
\hline Joe_Bay_2E & River & USGS & $25^{\circ} 13^{\prime} 55^{\prime \prime}$ & $-80^{\circ} 31 ' 28^{\prime \prime}$ & 547898.05 & 2790715.8 & Yes \\
\hline $\begin{array}{l}\text { McCormick_Creek_at_m } \\
\text { outh }\end{array}$ & River & USGS & $25^{\circ} 10^{\prime} 04^{\prime \prime}$ & -8043'54" & 527034.02 & 2783566.3 & Yes \\
\hline Mud_Creek_at_mouth & River & USGS & $25^{\circ} 12^{\prime} 12^{\prime \prime}$ & $-80^{\circ} 35^{\prime} 00^{\prime \prime}$ & 541970.27 & 2787541.3 & Yes \\
\hline Stillwater_Creek & River & USGS & $25^{\circ} 13^{\prime} 42^{\prime \prime}$ & $-80^{\circ} 29^{\prime} 11^{\prime \prime}$ & 551726.65 & 2790343.3 & Yes \\
\hline Upstream_Taylor_River & River & USGS & $25^{\circ} 12^{\prime} 42^{\prime \prime}$ & $-80^{\circ} 38^{\prime} 52^{\prime \prime}$ & 535475.28 & 2788445.5 & Yes \\
\hline Taylor_River_at_mouth & River & USGS & $25^{\circ} 11^{\prime} 28^{\prime \prime}$ & $-80^{\circ} 38^{\prime} 20^{\prime \prime}$ & 536376.84 & 2786171.8 & Yes \\
\hline Trouth_Creek_at_mouth & River & USGS & $25^{\circ} 12^{\prime} 54^{\prime \prime}$ & $-80^{\circ} 32^{\prime} 00^{\prime \prime}$ & 547003.17 & 2788849.7 & Yes \\
\hline West_Highway_Creek & River & USGS & $25^{\circ} 14^{\prime} 34^{\prime \prime}$ & $-80^{\circ} 26^{\prime} 49^{\prime \prime}$ & 555693.23 & 2791958.5 & Yes \\
\hline \multicolumn{8}{|l|}{ Gulf of Mexico (Tidal Rivers) } \\
\hline $\begin{array}{l}\text { Bottle_Creek_at_Rooker } \\
\text { y Branch }\end{array}$ & River & USGS & 2528'06" & $-80^{\circ} 51^{\prime} 15^{\prime \prime}$ & 514652.96 & 2816827.8 & Yes \\
\hline Broad_River_near_the_C & & & & & & & \\
\hline utoff & River & USGS & $25^{\circ} 30^{\prime} 06^{\prime \prime}$ & $-81^{\circ} 04^{\prime} 36^{\prime \prime}$ & 492287.91 & 2820513.2 & Yes \\
\hline Upstream_Broad_River & River & USGS & $25^{\circ} 30^{\prime} 04.7^{\prime \prime}$ & $-80^{\circ} 55^{\prime} 56^{\prime \prime}$ & 506811.43 & 2820460.2 & Yes \\
\hline $\begin{array}{l}\text { Chatham_River_near_the } \\
\text { _Watson_Place }\end{array}$ & River & USGS & $25^{\circ} 42^{\prime} 34^{\prime \prime}$ & $-81^{\circ} 14^{\prime} 58^{\prime \prime}$ & 474967.37 & 2843542.6 & Yes \\
\hline & & & & - & & & \\
\hline Harney_River & River & USGS & $25^{\circ} 25^{\prime} 52.4^{\prime \prime}$ & $81^{\circ} 05^{\prime} 08.3^{\prime \prime}$ & 491388.61 & 2812700.5 & Yes \\
\hline Lopez_River_Near_Lope & & & & & & & \\
\hline z_Campsite & River & USGS & $25^{\circ} 47^{\prime} 30^{\prime \prime}$ & $-81^{\circ} 17^{\prime} 58^{\prime \prime}$ & 469971.82 & 2852658.1 & Yes \\
\hline Lostmans_River_below_ & & & & & & & \\
\hline Second_Bay & River & USGS & $25^{\circ} 33^{\prime} 21^{\prime \prime}$ & $-81^{\circ} 09^{\prime} 52^{\prime \prime}$ & 483473.78 & 2826506.9 & Yes \\
\hline Upstream_Lostmans_Riv & & & & & & & \\
\hline er -- & River & USGS & $25^{\circ} 33^{\prime} 57^{\prime \prime}$ & $-80^{\circ} 59^{\prime} 41^{\prime \prime}$ & 500530.11 & 2827604.1 & Yes \\
\hline New_River_at_Sunday_ & & & & & & & \\
\hline Bay & River & USGS & $25^{\circ} 47^{\prime} 52^{\prime \prime}$ & $-81^{\circ} 15^{\prime} 19^{\prime \prime}$ & 474401.14 & 2853325.5 & Yes \\
\hline North_River_Upstream_ & & & & & & & \\
\hline of_Cutoff & River & USGS & $25^{\circ} 20^{\prime} 19^{\prime \prime}$ & $-80^{\circ} 54 ' 47^{\prime \prime}$ & 508742.28 & 2802458.4 & Yes \\
\hline Upstream_North_River & River & USGS & $25^{\circ} 21^{\prime} 29^{\prime \prime}$ & $-80^{\circ} 54^{\prime} 00^{\prime \prime}$ & 510026 & 2804598 & Yes \\
\hline Shark_River_Below_Gu & River & USGS & $25^{\circ} 22^{\prime} 31^{\prime \prime}$ & $-81^{\circ} 02^{\prime} 12^{\prime \prime}$ & 496303.9 & 2806516.3 & Yes \\
\hline
\end{tabular}


nboat_Island

Turner_River_nr_Chokol

oskee_Island

River

USGS

$25^{\circ} 49^{\prime} 44^{\prime \prime}$

$-81^{\circ} 20^{\prime} 29 "$

$465777.31 \quad 2856790.2$

Yes

Table A2. Canal Stations sorted by location.

\begin{tabular}{|c|c|c|c|c|c|c|c|}
\hline Station Name & Type of Station & $\begin{array}{l}\text { Operating } \\
\text { Agency }\end{array}$ & Latitude & Longitude & $\begin{array}{l}\text { UTM } \\
\text { Easting }\end{array}$ & $\begin{array}{l}\text { UTM } \\
\text { Northing }\end{array}$ & $\begin{array}{l}\text { Real } \\
\text { Time } \\
\text { Data } \\
\text { Daily }\end{array}$ \\
\hline \multicolumn{8}{|l|}{ C111 Canal } \\
\hline S18C_T & Canal structure & USGS & $25^{\circ} 19^{\prime} 15^{\prime \prime}$ & $-80^{\circ} 31 ' 30^{\prime \prime}$ & 547801.27 & 2800571.6 & Yes \\
\hline \multicolumn{8}{|l|}{ L28 Canal } \\
\hline L28S1 & Canal & SFWMD & $26^{\circ} 05^{\prime} 38^{\prime \prime}$ & $-80^{\circ} 50^{\prime} 34^{\prime \prime}$ & 515715.51 & 2886100.8 & Yes \\
\hline L28S2 & Canal & SFWMD & $26^{\circ} 05^{\prime} 38^{\prime \prime}$ & $-80^{\circ} 50^{\prime} 05^{\prime \prime}$ & 516521.07 & 2886101.8 & Yes \\
\hline S140_H & Canal structure & SFWMD & $26^{\circ} 10^{\prime} 18^{\prime \prime}$ & $-80^{\circ} 49^{\prime} 40^{\prime \prime}$ & 517207.4 & 2894700 & Yes \\
\hline S343A_T & Canal structure & SFWMD & $25^{\circ} 47^{\prime} 20^{\prime \prime}$ & $-80^{\circ} 51^{\prime} 20^{\prime \prime}$ & 514478.46 & 2852324.3 & Yes \\
\hline S343B_T & Canal structure & SFWMD & $25^{\circ} 46^{\prime} 41^{\prime \prime}$ & $-80^{\circ} 50^{\prime} 39^{\prime \prime}$ & 515620.35 & 2851105 & Yes \\
\hline \multicolumn{8}{|l|}{ L28 Interceptor Canal } \\
\hline S190_T & Canal structure & SFWMD & $26^{\circ} 16^{\prime} 60^{\prime \prime}$ & $-80^{\circ} 58^{\prime} 04^{\prime \prime}$ & 503213.05 & 2907051.9 & Yes \\
\hline \multicolumn{8}{|l|}{ L30 Canal } \\
\hline S335_H & Canal structure & SFWMD & $25^{\circ} 46^{\prime} 34^{\prime \prime}$ & $-80^{\circ} 28^{\prime} 59^{\prime \prime}$ & 551839.5 & 2851000.7 & Yes \\
\hline S335_T & Canal structure & SFWMD & $25^{\circ} 46^{\prime} 32^{\prime \prime}$ & $-80^{\circ} 28^{\prime} 59^{\prime \prime}$ & 551832.11 & 2850930.6 & Yes \\
\hline S337_T & Canal structure & SFWMD & $25^{\circ} 56^{\prime} 30^{\prime \prime}$ & $-80^{\circ} 26^{\prime} 28^{\prime \prime}$ & 555970.78 & 2869350.6 & Yes \\
\hline \multicolumn{8}{|l|}{ L31N Canal } \\
\hline L31N_1 & Canal & USGS & $25^{\circ} 44^{\prime} 54^{\prime \prime}$ & $-80^{\circ} 29^{\prime} 52^{\prime \prime}$ & 550362.54 & 2847920.9 & Yes \\
\hline L31N_3 & Canal & USGS & $25^{\circ} 44^{\prime} 48^{\prime \prime}$ & $-80^{\circ} 29^{\prime} 51^{\prime \prime}$ & 550391.1 & 2847736.4 & Yes \\
\hline L31N_4 & Canal & USGS & $25^{\circ} 42^{\prime} 07^{\prime \prime}$ & $-80^{\circ} 29^{\prime} 45^{\prime \prime}$ & 550577.16 & 2842784.6 & Yes \\
\hline L31N_5 & Canal & USGS & $25^{\circ} 41^{\prime} 10^{\prime \prime}$ & $-80^{\circ} 29^{\prime} 49^{\prime \prime}$ & 550472.35 & 2841030.9 & Yes \\
\hline L31N_7 & Canal & USGS & $25^{\circ} 39^{\prime} 48^{\prime \prime}$ & $-80^{\circ} 29^{\prime} 53^{\prime \prime}$ & 550370.42 & 2838508.1 & Yes \\
\hline L31NN & Canal & SFWMD & $25^{\circ} 44^{\prime} 47^{\prime \prime}$ & $-80^{\circ} 29^{\prime} 51^{\prime \prime}$ & 550391.22 & 2847705.7 & Yes \\
\hline L31NS & Canal & SFWMD & $25^{\circ} 42^{\prime} 08^{\prime \prime}$ & $-80^{\circ} 29^{\prime} 45^{\prime \prime}$ & 550577.04 & 2842815.4 & Yes \\
\hline G211_H & Canal structure & SFWMD & 2539'36" & $-80^{\circ} 29^{\prime} 52^{\prime \prime}$ & 550398.42 & 2838121.2 & Yes \\
\hline G211_T & Canal structure & SFWMD & 2539'33" & $-80^{\circ} 29^{\prime} 52^{\prime \prime}$ & 550404.06 & 2838047.2 & Yes \\
\hline \multicolumn{8}{|l|}{ L31W Canal } \\
\hline S175_H & Canal structure & SFWMD & $25^{\circ} 25^{\prime} 05^{\prime \prime}$ & $-80^{\circ} 34^{\prime} 26^{\prime \prime}$ & 542862.36 & 2811294.5 & Yes \\
\hline S175_T & Canal structure & SFWMD & $25^{\circ} 25^{\prime} 03^{\prime \prime}$ & $-80^{\circ} 34^{\prime} 26^{\prime \prime}$ & 542863.83 & 2811249.8 & Yes \\
\hline S332D_T & Canal structure & SFWMD & $25^{\circ} 28^{\prime} 59^{\prime \prime}$ & $-80^{\circ} 33^{\prime} 51^{\prime \prime}$ & 543818.91 & 2818498.4 & Yes \\
\hline \multicolumn{8}{|l|}{ L38E Canal } \\
\hline S141_T & Canal structure & SFWMD & $26^{\circ} 09^{\prime} 03^{\prime \prime}$ & $-80^{\circ} 26^{\prime} 33^{\prime \prime}$ & 555712.99 & 2892496.3 & No \\
\hline S142_H & Canal structure & SFWMD & $26^{\circ} 09^{\prime} 37^{\prime \prime}$ & $-80^{\circ} 26^{\prime} 41^{\prime \prime}$ & 555489.71 & 2893543 & No \\
\hline S143_T & Canal structure & SFWMD & $26^{\circ} 10^{\prime} 34^{\prime \prime}$ & $-80^{\circ} 26^{\prime} 54^{\prime \prime}$ & 555136.92 & 2895305.4 & No \\
\hline S34_H & Canal structure & SFWMD & $26^{\circ} 09^{\prime} 02^{\prime \prime}$ & $-80^{\circ} 26^{\prime} 33^{\prime \prime}$ & 555714.5 & 2892479.6 & Yes \\
\hline S7_T & Canal structure & SFWMD & $26^{\circ} 20^{\prime} 07^{\prime \prime}$ & $-80^{\circ} 32^{\prime} 12^{\prime \prime}$ & 546248.38 & 2912887.5 & Yes \\
\hline \multicolumn{8}{|l|}{ L39 Canal } \\
\hline S10A_H & Canal structure & USGS & $26^{\circ} 21^{\prime} 36^{\prime \prime}$ & $-80^{\circ} 18^{\prime} 45^{\prime \prime}$ & 568592.55 & 2915744.4 & Yes \\
\hline S10C_H & Canal structure & USGS & $26^{\circ} 22^{\prime} 18^{\prime \prime}$ & $-80^{\circ} 21^{\prime} 09^{\prime \prime}$ & 564597.91 & 2917008.9 & Yes \\
\hline S10D_H & Canal structure & USGS & $26^{\circ} 23^{\prime} 19^{\prime \prime}$ & $-80^{\circ} 22^{\prime} 54^{\prime \prime}$ & 561683.3 & 2918858.3 & Yes \\
\hline S39_H & Canal structure & SFWMD & $26^{\circ} 21^{\prime} 21^{\prime \prime}$ & $-80^{\circ} 17^{\prime} 53^{\prime \prime}$ & 570050.07 & 2915284.6 & Yes \\
\hline \multicolumn{8}{|l|}{ L40 Canal } \\
\hline G300_T & Canal structure & SFWMD & $26^{\circ} 40^{\prime} 37^{\prime \prime}$ & $-80^{\circ} 21^{\prime} 48^{\prime \prime}$ & 563360.3 & 2950824 & Yes \\
\hline \multicolumn{8}{|l|}{ L6 Canal } \\
\hline G339_H & Canal structure & SFWMD & $26^{\circ} 27^{\prime} 48^{\prime \prime}$ & $-80^{\circ} 27^{\prime} 09^{\prime \prime}$ & 554571.68 & 2927121.8 & Yes \\
\hline G339_T & Canal structure & SFWMD & $26^{\circ} 27^{\prime} 48^{\prime \prime}$ & $-80^{\circ} 27^{\prime} 10^{\prime \prime}$ & 554557.92 & 2927099 & Yes \\
\hline \multicolumn{8}{|l|}{ L7 Canal } \\
\hline G301_T & Canal structure & SFWMD & $26^{\circ} 40^{\prime} 31^{\prime \prime}$ & $-80^{\circ} 22^{\prime} 49^{\prime \prime}$ & 561649.23 & 2950621.9 & Yes \\
\hline \multicolumn{8}{|l|}{ Miami Canal } \\
\hline S151_H & Canal structure & SFWMD & $26^{\circ} 00^{\prime} 42^{\prime \prime}$ & $-80^{\circ} 30^{\prime} 36^{\prime \prime}$ & 549024.28 & 2877054.8 & Yes \\
\hline
\end{tabular}




\begin{tabular}{|c|c|c|c|c|c|c|c|}
\hline S151_T & Canal structure & SFWMD & $26^{\circ} 00^{\prime} 40^{\prime \prime}$ & $-80^{\circ} 30^{\prime} 35^{\prime \prime}$ & 549066.07 & 2877020.9 & Yes \\
\hline S31_H & Canal structure & SFWMD & $25^{\circ} 56^{\prime} 33^{\prime \prime}$ & $-80^{\circ} 26^{\prime} 26^{\prime \prime}$ & 556014 & 2869447.1 & Yes \\
\hline S339_H & Canal structure & SFWMD & $26^{\circ} 13^{\prime} 04^{\prime \prime}$ & $-80^{\circ} 41^{\prime} 27^{\prime \prime}$ & 530880.38 & 2899828.6 & Yes \\
\hline S339_T & Canal structure & SFWMD & $26^{\circ} 13^{\prime} 01^{\prime \prime}$ & $-80^{\circ} 41^{\prime} 25^{\prime \prime}$ & 530927.84 & 2899756 & Yes \\
\hline S340_H & Canal structure & SFWMD & $26^{\circ} 07^{\prime} 09^{\prime \prime}$ & $-80^{\circ} 36^{\prime} 48^{\prime \prime}$ & 538669.8 & 2888945.9 & Yes \\
\hline S340_T & Canal structure & SFWMD & $26^{\circ} 07^{\prime} 06^{\prime \prime}$ & $-80^{\circ} 36^{\prime} 45^{\prime \prime}$ & 538735.44 & 2888851.7 & Yes \\
\hline S8_T & Canal structure & USGS & $26^{\circ} 19^{\prime} 52^{\prime \prime}$ & $-80^{\circ} 46^{\prime} 27^{\prime \prime}$ & 522523.9 & 2912387.2 & Yes \\
\hline \multicolumn{8}{|c|}{ North Feeder Canal } \\
\hline S190_H & Canal structure & SFWMD & $26^{\circ} 17^{\prime} 03^{\prime \prime}$ & $-80^{\circ} 58^{\prime} 05^{\prime \prime}$ & 503190.12 & 2907144.7 & Yes \\
\hline \multicolumn{8}{|l|}{ Pennsuco Wetlands } \\
\hline NWWF & Canal & USGS & $25^{\circ} 53^{\prime} 28^{\prime \prime}$ & $-80^{\circ} 25^{\prime} 13^{\prime \prime}$ & 558093.5 & 2863794.9 & Yes \\
\hline S380_H & Canal structure & SFWMD & $25^{\circ} 45^{\prime} 41^{\prime \prime}$ & $-80^{\circ} 26^{\prime} 54^{\prime \prime}$ & 555313.81 & 2849371.9 & Yes \\
\hline \multicolumn{8}{|l|}{ Tamiami Canal } \\
\hline G119_H & Canal structure & SFWMD & $25^{\circ} 45^{\prime} 40^{\prime \prime}$ & $-80^{\circ} 28^{\prime} 39^{\prime \prime}$ & 552405.37 & 2849342.9 & No \\
\hline G119_T & Canal structure & SFWMD & $25^{\circ} 45^{\prime} 40^{\prime \prime}$ & $-80^{\circ} 28^{\prime} 37^{\prime \prime}$ & 552454.35 & 2849344.1 & No \\
\hline S12A_H & Canal structure & USGS & $25^{\circ} 45^{\prime} 44^{\prime \prime}$ & $-80^{\circ} 49^{\prime} 16^{\prime \prime}$ & 517940.03 & 2849363.6 & Yes \\
\hline S12B_H & Canal structure & USGS & $25^{\circ} 45^{\prime} 44^{\prime \prime}$ & $-80^{\circ} 46^{\prime} 10^{\prime \prime}$ & 523115.62 & 2849372.2 & Yes \\
\hline S12C_H & Canal structure & USGS & $25^{\circ} 45^{\prime} 44^{\prime \prime}$ & $-80^{\circ} 43^{\prime} 37^{\prime \prime}$ & 527382.65 & 2849386.2 & Yes \\
\hline S12D_H & Canal structure & USGS & $25^{\circ} 45^{\prime} 44^{\prime \prime}$ & $-80^{\circ} 40^{\prime} 54^{\prime \prime}$ & 531912.9 & 2849401.7 & Yes \\
\hline S333_H & Canal structure & SFWMD & $25^{\circ} 45^{\prime} 43^{\prime \prime}$ & $-80^{\circ} 40^{\prime} 27^{\prime \prime}$ & 532668.15 & 2849372.8 & Yes \\
\hline S333_T & Canal structure & SFWMD & $25^{\circ} 45^{\prime} 42^{\prime \prime}$ & $-80^{\circ} 40^{\prime} 23^{\prime \prime}$ & 532774.07 & 2849335.3 & Yes \\
\hline S334_H & Canal structure & SFWMD & $25^{\circ} 45^{\prime} 41^{\prime \prime}$ & $-80^{\circ} 30^{\prime} 10^{\prime \prime}$ & 549864.37 & 2849342.3 & Yes \\
\hline S334_T & Canal structure & SFWMD & $25^{\circ} 45^{\prime} 41^{\prime \prime}$ & $-80^{\circ} 30^{\prime} 05^{\prime \prime}$ & 549992.45 & 2849340.4 & Yes \\
\hline S336_H & Canal structure & SFWMD & $25^{\circ} 45^{\prime} 40^{\prime \prime}$ & $-80^{\circ} 29^{\prime} 50^{\prime \prime}$ & 550405.97 & 2849339.8 & Yes \\
\hline S336_T & Canal structure & SFWMD & $25^{\circ} 45^{\prime} 40^{\prime \prime}$ & $-80^{\circ} 29^{\prime} 48^{\prime \prime}$ & 550486.99 & 2849335.3 & Yes \\
\hline \multicolumn{8}{|c|}{ Water Conservation Ar } \\
\hline S140_T & Canal structure & SFWMD & $26^{\circ} 10^{\prime} 18^{\prime \prime}$ & $-80^{\circ} 49^{\prime} 38^{\prime \prime}$ & 517275.03 & 2894702.9 & Yes \\
\hline
\end{tabular}




\section{Appendix B: EDEN NetCDF Data Format}

NetCDF (Network Common Data Form) is a set of freely-distributed software libraries and machine-independent binary data formats that support the creation, access, and sharing of large array-oriented scientific data. This format replaces the bulky file structure and difficult file management of ESRI GRIDS for EDEN data. It also allows EDEN applications to run on computers without ArcGIS installations.

NetCDF was originally created for climatological datasets and is used by groups such as NOAA, Los Alamos National Laboratory, and Woods Hole Oceanographic Institution. The netCDF software was developed out of the NASA CDF data model by the Unidata Program Center, sponsored by the National Science Foundation, and with contributions from the netCDF user community. An increasing number of commercial and free software applications and utilities support netCDF including ESRI ArcGIS(as of version 9.2) and MATLAB. Some of the features of netCDF that add to its popularity include:

1. Support for time-series of array-oriented data sets

2. Direct access of data allows for efficient access of small subsets of large datasets

3. A netCDF file can be self-describing. That is, it can include information about the data it contains

4. NetCDF files are portable and can be accessed by computers with different methods of storing values

5. One writer and multiple readers may simultaneously access the same netCDF file in a shared network

6. Data may be appended to a properly structured netCDF file without copying the dataset or redefining its structure

ArcGIS users can easily use EDEN netCDF datasets. EDEN netCDF datasets follow the climate and forcasting (CF) metadata conventions which specify spatial and temporal attributes included in the files (Table 1). This is the critical element in netCDF that allows integration with geographic information systems (GIS) such as ArcGIS. ArcGIS (versions 9.2 and later) has the ability to read CF-compliant netCDF files.

The most important thing for users to know about EDEN water stage data files is that each file contains 3 months (a quarter) of daily datasets. So, for example, the data for every day in 2002 will be stored in 4 files: 2002_q1.nc, 2002_q2.nc, 2002_q3.nc, and 2002_q4.nc. The digital elevation model, which is necessary for the creation of EDEN water depth datasets, is contained in a file named dem.nc.

The JEM (Joint Ecological Modeling) Lab at the University of Florida, Fort Lauderdale Research and Education Center provides utilities for the viewing and analysis of EDEN netCDF files. 
Table B1. CF-compliant metadata in the header of EDEN water stage netCDF files provide spatial information for projecting the data in a GIS, as well as the start date and time step for the time-series of data in the file.

\begin{tabular}{|l|l|}
\hline Attribute & Example Value in EDEN stage data files \\
\hline Creation Date & June 1, 2007 \\
\hline Conventions & CF-1.0 \\
\hline Source & JEM NetCDF writer \\
\hline Layer name & stage \\
\hline Layer Version & 1.1 \\
\hline Spatial Reference & NAD_1983_UTM_Zone_17N \\
\hline Datum & North_American_1983 \\
\hline Spheroid & GRS_1980 \\
\hline Prime Meridian & Greenwich, 0.0 \\
\hline Angular Units & Degree (0.0174532925199433) \\
\hline Projection & Transverse_Mercator \\
\hline Linear Units & Meter (1.0) \\
\hline False Easting & 500000.0 \\
\hline False Northing & 0.0 \\
\hline Central Meridian & -81.0 \\
\hline Scale Factor & 0.9996 \\
\hline Latitude of Origin & 0.0 \\
\hline Grid Mapping Units & cm \\
\hline Starting Date & $2000-01-01 T 12: 00: 00 Z$ \\
\hline Time Step Units & days \\
\hline
\end{tabular}

Additional sources of information

About netCDF: http://www.unidata.ucar.edu/software/netcdf/

About CF Conventions: http://www.cgd.ucar.edu/cms/eaton/cf-metadata/CF-current.html 


\section{Appendix C: Constructing Confidence Index Maps for Interpolated Water Surface}

The final confidence index map for an interpolated water surface is a geometric mean of these attributes:

Canal Index - The closer a grid cell is to a canal the lower the confidence.

Error Index - Is derived from cross validation errors computed by the water surface model for each station that had data. The error represents the difference between measured and predicted water level for a station, where the lower the error the higher the confidence. Thiessen polygons created for each station with data are used to project cross-validation errors at a station (point information) to a spatial extent representing the influence of a station on its surrounding area. Distance Index - Composed of multiple ring buffers placed around stations with data. The distance index represents the distance to the nearest station; up to 10 rings can be placed around a station with each ring representing 1000 meters. The closer a grid cell is to a station the higher the confidence at that grid cell.

\section{Create Canal Index}

This feature class will be used for determining confidence index values depending on how close a grid cell on the predicted surface is to a canal (i.e. least confidence when within 0 to 1000 meters of a canal; mid confidence when within 1000 to 2000 meters of a canal; most confidence when beyond 2000 meters of a canal.

Because the location of canals doesn't normally move, this index layer only needs to be created one time. Daily confidence indices can all use the same canal index.

A multiple ring buffer is created around a shapefile of canals. The buffer distances are 1000 and $2000 \mathrm{~m}$.

Index values are assigned to a new field in the table for the new buffer layer such that

If buffer distance $>2000$ then Canal_index $=1$

If buffer distance $=2000$ then Canal_index $=0.5$

If buffer distance $=1000$ then Canal_index $=0.01$

The canal index buffer shapefile is then clipped to the EDEN boundary. 


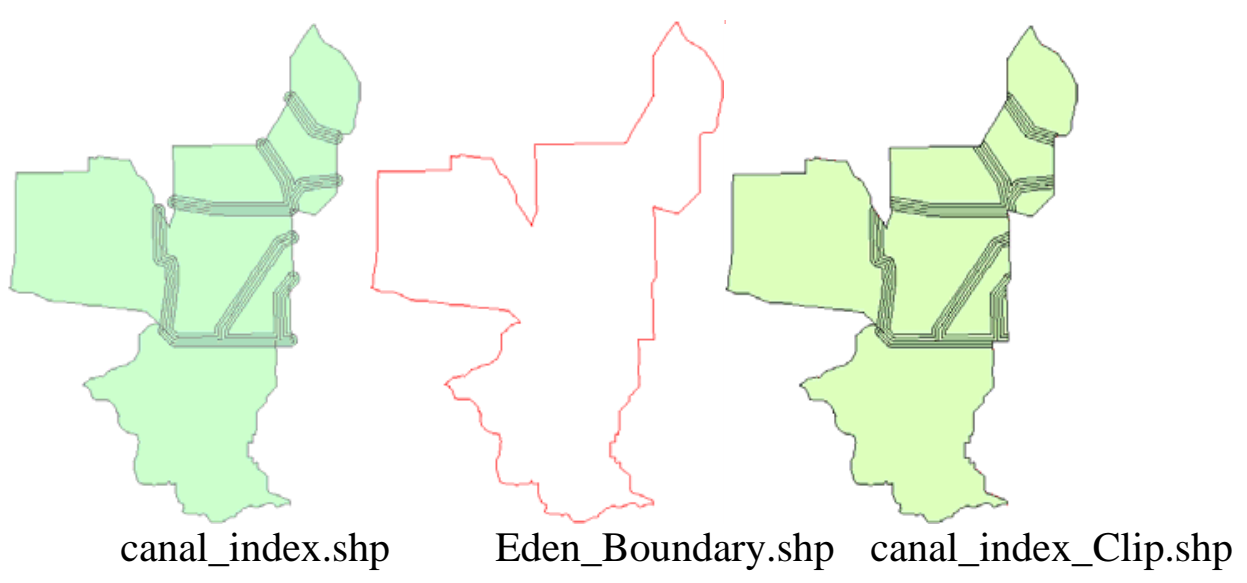

\section{Create Error Index}

This feature class will be used for determining confidence index values depending on cross-validation errors of the closest water stage gage to a grid cell on the predicted surface.

Add XY data for the daily median txt file for all stations operating on the particular day being indexed.

Append the fields from the cross validation table to the median shapefile (in ArcGIS on the Join Data dialog box, this is option 2, Each point will be given all the attributes...”.

Remove all stations that are not used to create the final confidence index. The final confidence index is based just on EDEN stations not used in canal linear interpolation or certain outlier stations that may unjustly skew the confidence.

Excluded from processing, the final confidence index dataset are canal interpolation (i.e., S10A-UP), some outlier stations (i.e., BCA10+) that had data on the date being processed and coastal stations. Appendix A lists all the gaging stations and notes the canal stations. Excluded stations are listed in Table C1.

\section{Create absolute cross-validation error index}

In the just created stations shapefile with unused stations removed, index values are assigned to a new field such that:

If Abs ( [Error] ) $<=5$ then CV_index $=1$

If Abs ( [Error] ) $>5$ and Abs ( [Error] $)<=10$ then CV_index $=0.8$

If Abs ( [Error] ) $>10$ and Abs ( [Error] $)<=15$ then CV_index $=0.6$

If Abs ( [Error] ) $>15$ and Abs ( [Error] $)<=20$ then CV_index $=0.4$

If Abs ( [Error] ) $>20$ and Abs ( [Error] $)<=25$ then CV_index $=0.2$

If Abs ( [Error] $)>25$ then CV_index $=0.01$ 
where $\operatorname{Abs}(\{E r r o r\})$ is the absolute value of the cross-validation error.

Table C1. Water stage stations excluded from the cross-validation error confidence index.

\begin{tabular}{|ll|}
\hline Station & Area \\
\hline BCA10+ & BCNP \\
BCA11+ & BCNP \\
BCA19+ & BCNP \\
LOOP2+H & BCNP \\
LOOP2+T & BCNP \\
EVER8 & ENP \\
S332D-T & L31W Canal \\
L31W & ENP \\
MCCORMICK & Florida Bay \\
TAYLORRIVER & Florida Bay \\
MUD & Florida Bay \\
TAYLOR_UP & Florida Bay \\
TROUT & Florida Bay \\
STILLWATER & Florida Bay \\
\hline
\end{tabular}

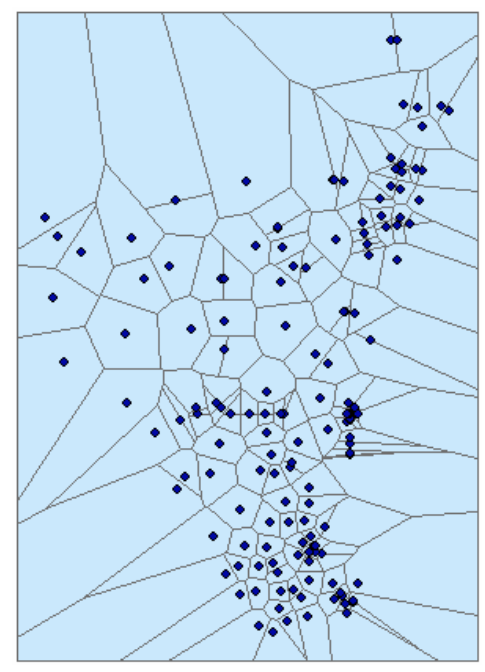

\section{Create Thiessen Polygons From Point (stations) Layer}

Thiessen polygon layer is created from the station point layer. The resulting Thiessen polygon layer is created with the same attributes as the point coverage layer including the error index. 


\section{Create Distance Buffer Layer}

This feature class will be used for determining confidence index values depending on how close a grid cell on the predicted surface is to water stage monitoring stations.

The distance layer is based on the "distance to the nearest station". This will be done by creating multiple ring buffers around stations with data and using distance values of $1000,2000,3000,4000,5000,6000,7000,8000,9000$, and 10000 meters from the nearest station. Overlapping boundaries are dissolved.

Input is the station point layer,

Clip the multi ring distance buffer layer using the Eden boundary.

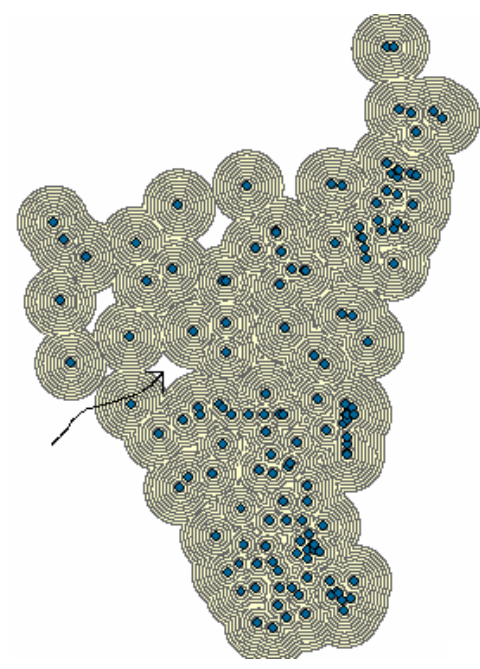

\begin{tabular}{|c|c|c|c|c|}
\hline \multicolumn{5}{|c|}{ Attributes of DistBuff20000101 } \\
\hline & FID & Shape & \multicolumn{2}{|l|}{ DistBuff } \\
\hline \multirow[t]{10}{*}{ - } & 0 & Polygon & & 1000 \\
\hline & & Polygon & & 2000 \\
\hline & & Polygon & & 3000 \\
\hline & & Polygon & & 4000 \\
\hline & & Polygon & & 5000 \\
\hline & & Polygon & & 6000 \\
\hline & & Polygon & & 7000 \\
\hline & & Polygon & & 8000 \\
\hline & & Polygon & & 9000 \\
\hline & & Polygon & & 10000 \\
\hline & 14] 4 | & 1 & Show: All & Selected \\
\hline
\end{tabular}

The distance buffers will be used to generate the distance index, but not until after the distance buffer is combined with the canal index and error index. If the distance index was calculated from the distance buffer at this point, then some of the areas would not have a distance index: 


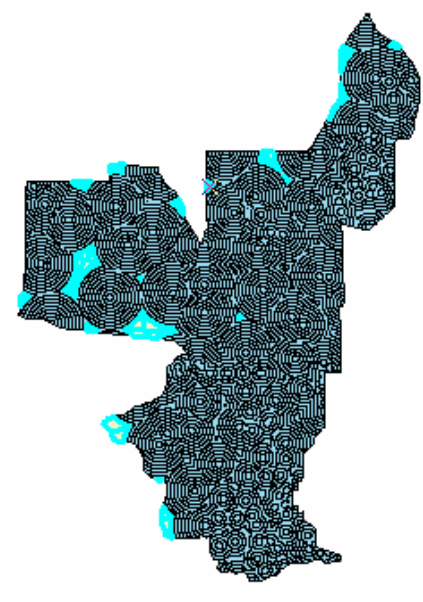

highlighted areas wouldn't have a distance index

\section{Combine the Index Layers}

Use the Union command to overlay the two index layers (canal and error) and distance buffer layer. Their attribute tables can not be joined because they all have different numbers of records and none of them have a field in common such as a station name. The union is clipped to the EDEN boundary.

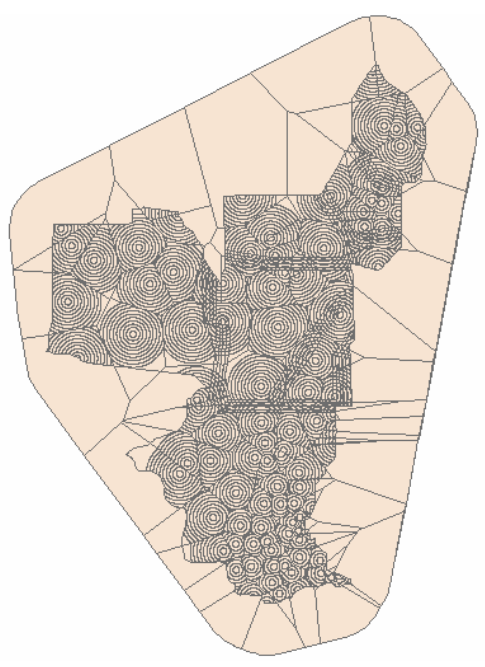

Union

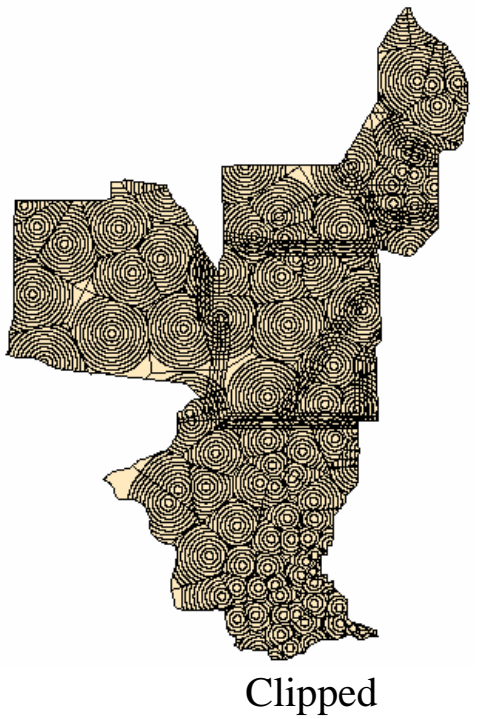

Clipped

\section{Calculate Distance Index}

Now that all index layers have been combined into one layer and all possible polygons have been created, the distance index can be correctly calculated. 
For the combined layer, index values are assigned to a new field in the table such that:

If [DistBuff] $>0$ and [DistBuff] $<=1000$ then index $=1$

If [DistBuff] $>1000$ and [DistBuff] $<=2000$ then Dist_index $=0.9$

If [DistBuff] $>2000$ and [DistBuff] $<=3000$ then Dist_index $=0.8$

If [DistBuff] $>3000$ and [DistBuff] $<=4000$ then Dist_index $=0.7$

If [DistBuff] $>4000$ and [DistBuff] $<=5000$

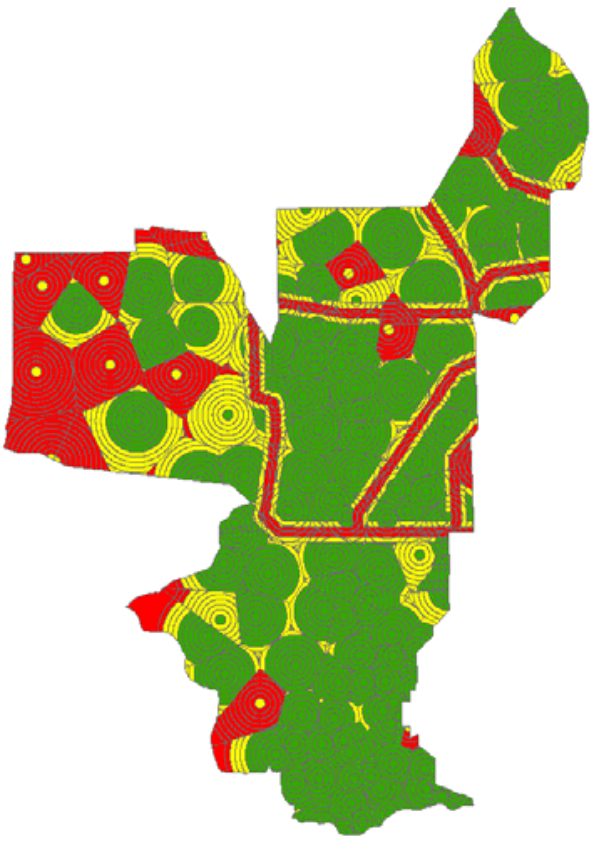
then Dist_index $=0.6$

If [DistBuff] $>5000$ and [DistBuff] $<=6000$ then Dist_index $=0.5$ If [DistBuff] $>6000$ and [DistBuff] $<=7000$ then Dist_index $=0.4$ If [DistBuff] $>7000$ and [DistBuff] $<=8000$ then Dist_index $=0.3$ If [DistBuff] $>8000$ and [DistBuff] $<=9000$ then Dist_index $=0.2$ If [DistBuff] $>9000$ or [DistBuff] $=0$ then Dist_index $=0.1$

\section{Create Final Confidence Index}

For the combined layer, index values are assigned to a new field in the table so that:

$$
C=(\text { Canal_index })^{2 / 5} *(\text { Dist_index })^{2 / 5} *\left(C V \_ \text {index }\right)^{1 / 5}
$$

The weighted geometric mean assigns more weight to the distance and canal indexes than to the cross validation error index. Less weight is assigned to this last index because it is based on predicted water level values when removing a station that is actually present that day. This skews the result less favorably for areas in close proximity, and directly at, a gage station.

\section{Transform the index to qualitative terms.}

Add a new field to the final table such that:

If $[C]<=0.39$ then index $=$ "Low" If $[C]>0.69$ then index= "High" 